Portland State University

PDXScholar

$1-1-2010$

\title{
Occurrence and Concentrations of Caffeine in Seawater from the Oregon Coast and Potential Effects on the Dominant Mussel, Mytilus californianus
}

Zoe Rodriguez del Rey

Portland State University

Follow this and additional works at: https://pdxscholar.library.pdx.edu/open_access_etds Let us know how access to this document benefits you.

\section{Recommended Citation}

Rodriguez del Rey, Zoe, "Occurrence and Concentrations of Caffeine in Seawater from the Oregon Coast and Potential Effects on the Dominant Mussel, Mytilus californianus" (2010). Dissertations and Theses. Paper 722.

https://doi.org/10.15760/etd.722

This Thesis is brought to you for free and open access. It has been accepted for inclusion in Dissertations and Theses by an authorized administrator of PDXScholar. Please contact us if we can make this document more accessible: pdxscholar@pdx.edu. 


\title{
Occurrence and Concentrations of Caffeine in Seawater from the Oregon Coast and Potential Effects on the Dominant Mussel, Mytilus californianus
}

\author{
by \\ Zoe Rodriguez del Rey \\ A thesis submitted in partial fulfillment of the \\ requirements for the degree of \\ Master of Science \\ in \\ Environmental Science and Resources
}

Thesis Committee:

Elise F. Granek, Chair

Catherine E. de Rivera

Steve R. Sylvester

Bradley Buckley

Portland State University
2010 


\section{ABSTRACT}

Caffeine, a biologically active drug with many known molecular targets, is recognized as a contaminant of aquatic systems including marine systems. Although the concentrations of caffeine reported from aquatic systems are low (ng/L to $\mu \mathrm{g} / \mathrm{L})$, harmful ecological effects not detected by traditional toxicity tests could occur as a result of caffeine contamination. The goals of this thesis project were to: 1) quantify concentrations of caffeine occurring in the coastal ocean off of the Oregon Coast and to determine if higher levels were correlated with proximity to caffeine pollution sources; and 2) investigate the sub-lethal cellular toxicity of environmentally relevant concentrations of caffeine on Mytilus californianus, an intertidal mussel that is one of the dominant species of the Oregon Coast.

Caffeine was analyzed at 14 locations in the coastal ocean off of the Oregon Coast. Sampling locations were stratified between populated areas identified as having sources of caffeine pollution and sites located in sparsely populated areas not in proximity to major caffeine pollution sources. Caffeine concentrations were also measured in the major water body discharging near sampling 
locations. Caffeine was detected in water from the coastal ocean off of the Oregon coast at concentrations ranging from below the reporting limit to $44.7 \mathrm{ng} / \mathrm{L}$. The occurrence and concentrations of caffeine in the coastal ocean did not correspond well with pollution threats from population density and point and non-point sources, but did correspond with a storm event occurrence. Caffeine concentrations in rivers and estuaries draining to the coast ranged from below the reporting limit to $152.2 \mathrm{ng} / \mathrm{L}$.

Hsp70, a molecular biomarker of cellular stress, was used to investigate the sub-lethal toxicity of environmentally relevant concentrations of caffeine to the mussel M. californianus. Hsp70 concentrations in the gill and mantle tissue of mussels exposed to $0.05,0.2$, and 0.5 $\mu \mathrm{g} / \mathrm{L}$ of caffeine for 10, 20, and 30 days were compared to basal levels in control mussels. Hsp70 in the gill tissue of M. californianus had an initial attenuation of the stress protein followed by a significant albeit moderate up-regulation relative to controls in all but the $0.5 \mu \mathrm{g} / \mathrm{L}$ treatment. Hsp70 in the mantle tissue of mussels exposed to caffeine did not differ from control mussels.

This study confirms the presence of caffeine in Oregon's coastal ocean and provides laboratory evidence 
that environmentally relevant concentrations of caffeine can exert an effect on $M$. californianus gill tissue at the molecular-level. 


\section{ACKNOWLEDGEMENTS}

This project was funded in part by a Portland state University Faculty Enhancement Grant to Elise Granek and Brad Buckley and by an Oregon Sea Grant Program Development Grant to Elise Granek. I would like to thank Kerry Griffin of NOAA's National Marine Fisheries Service and the NOAA Portland, Oregon Office for providing additional funding for supplies.

I would like to thank the following people for their generous help with this project:

My thesis committee for support in completing this project. A special thanks to steve Sylvester for guiding me through the growing pains of graduate school.

Lorne Isabelle, Wentai Luo, and James Pankow from Portland State University for GC-MS analysis. I would not have been able to complete this project without your generous help. Lorne and Wentai, I learned a lot from both of you and I am deeply grateful.

Brad Buckley for providing laboratory space, equipment, and supplies for the mussel experiment and immunochemical assay. A special thanks to the Buckley Lab 
graduate students for bench space and for always being so helpful.

Linda George for providing access to field transportation.

Paul Pettus, Amanda Kelly, Ben Prital, Emily Swanson, Charissa Stair, Becca Aaby, David Lock, Huy Le, and Tiffany Gerhart for help in the field and laboratory, and camaraderie. A very special thanks to Malcolm Staudinger and Caitlyn Peake for endless hours of help. I can never repay your generosity and dedication.

To Julie Whitbeck and Michael Poirrier, thank you for being my mentors. I respect your dedication to science and to the City of New Orleans.

To the ESR undergraduate students that I had the pleasure to TA at PSU: you enriched my graduate experience and helped me to maintain perspective. Thank you.

A special thanks to Katherine Smith and Brie Bergdahl for processing when things got frustrating. To my dear friend Natalie Marsh, thank you for believing in me.

To Mayda Pla, Betty Hernandez, Joel Morejon, Deborah Munoz, Janine Toledo, Jesse Hernandez, and Tyler Hernandez, you are an amazing family; thank you for all your support. 


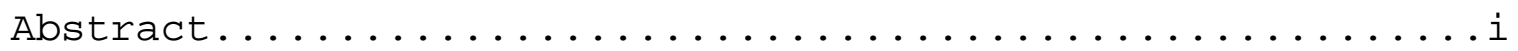

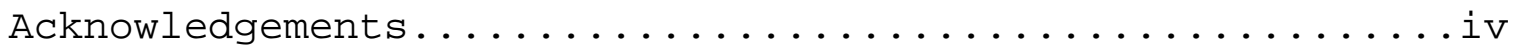

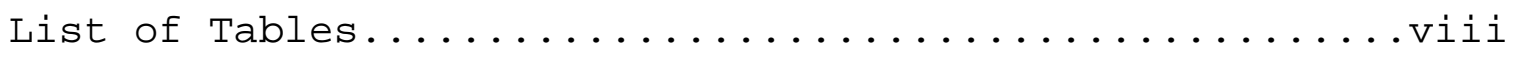

List of Figures...............................

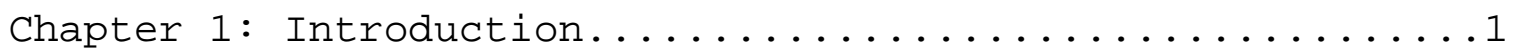

Chapter 2: Occurrence and Concentration of Caffeine in Seawater from the Oregon coast

Introduction $\ldots \ldots \ldots \ldots \ldots \ldots \ldots \ldots \ldots \ldots \ldots \ldots \ldots \ldots \ldots \ldots \ldots \ldots$

Methods

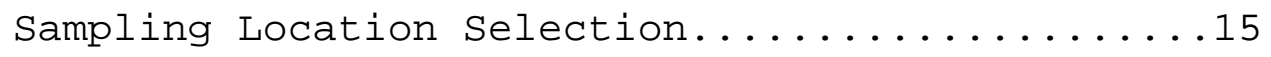

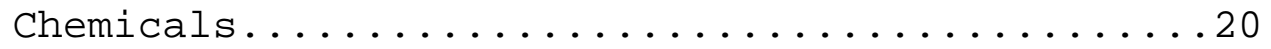

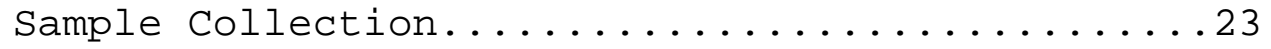

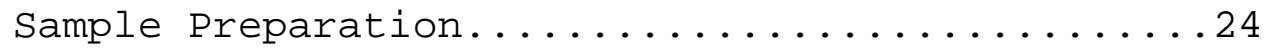

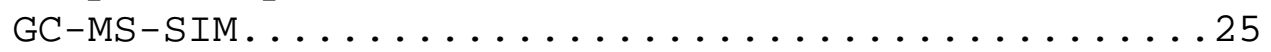

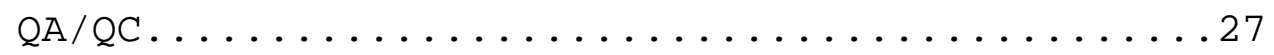

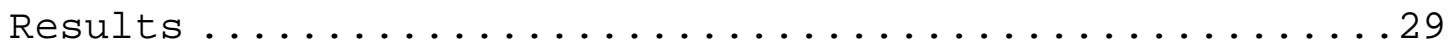

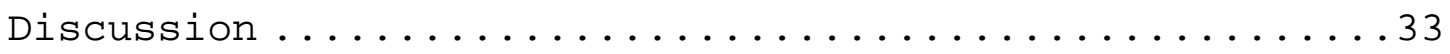

Chapter 3: Expression of Hsp70, a Molecular Marker of Stress, in the Gill and Mantle Tissue of Mytilus californianus Exposed to Low Concentrations of Caffeine

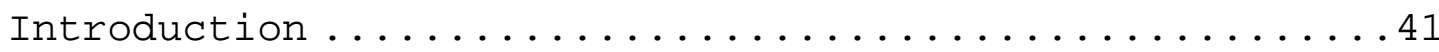

Methods

Study Organisms and Acclimation Conditions.....49

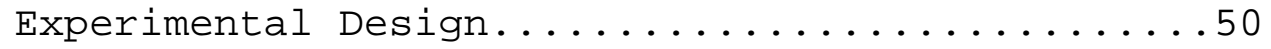

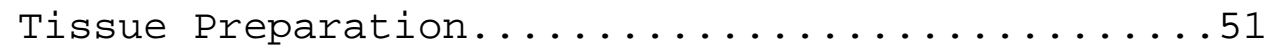

Electrophoresis and Immunochemical Assay for

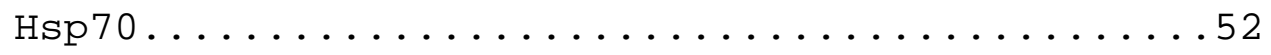

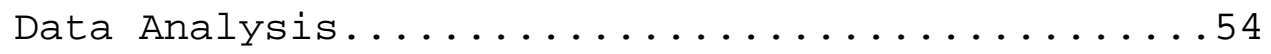

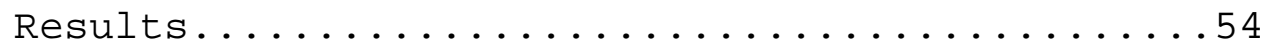




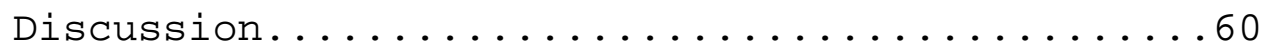

Chapter 4 : Conclusions......................68

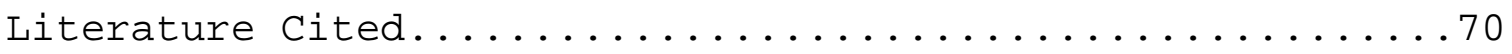

Appendix A: Record of Modifications to Initial Study

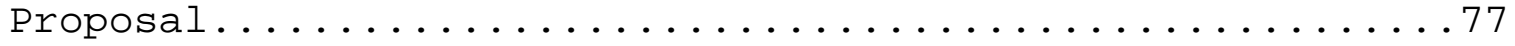




\section{LIST OF TABLES}

2.1 The locations and concentrations of caffeine reported from seawater in previous studies ....... 6

2.2 Criteria used to select sampling locations with caffeine pollution threats ...............16

2.3 Base layers used for the sampling location

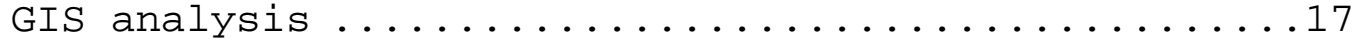

2.4 The seven most populated areas in the Oregon

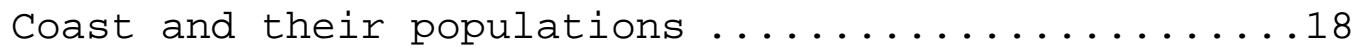

2.5 Selected sampling locations listed from north to south and pollution threat .............19

2.6 Summary of GC-MS analytical conditions .........25

2.7 Caffeine concentrations and salinity in coastal ocean samples and water bodies adjacent to coastal ocean sampling sites

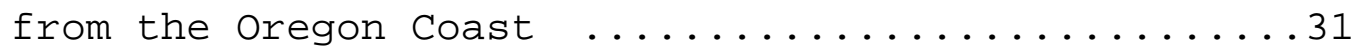

3.1 Summary of two-way ANOVA results for the

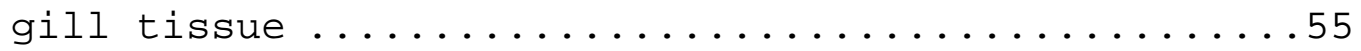

3.2 Summary of two-way ANOVA results for the

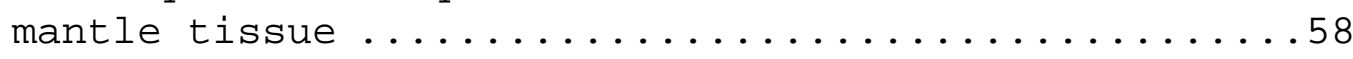




\section{LIST OF FIGURES}

2.1 Final sampling Locations in the South Oregon

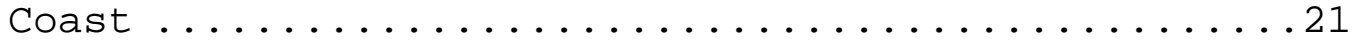

2.2 Final sampling Locations in the South Oregon

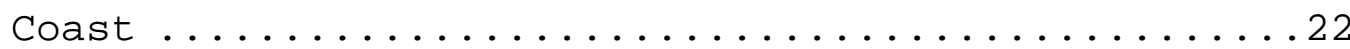

2.3 Sample chromatogram and mass spectrum for a

$5 \mathrm{ng} / \mathrm{L}$ standard solution run in SIM mode .........27

2.4 Sample chromatogram of a $5 \mathrm{ng} / \mathrm{L}$ standard

solution with the quantifier ions for

caffeine and ${ }^{13} \mathrm{C}_{3}-$ labeled caffeine overlaid

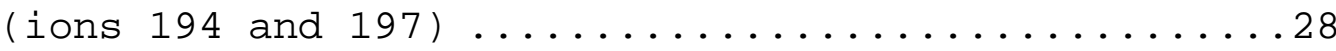

2.5 Relationship between caffeine measured in

the coastal ocean and in adjacent water

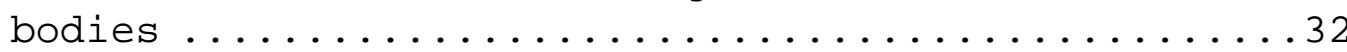

3.1 Cellular pathways and the specific points at

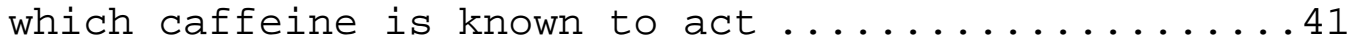

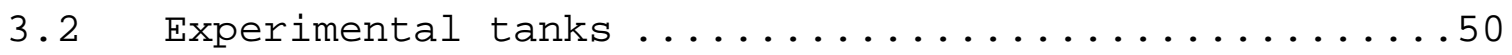

3.3 Sample Western blots from selected gill and mantle tissue samples .....................54

3.4 Relative Hsp70 expression in the gill tissue of M. californianus exposed to three concentrations of caffeine for 10, 20, and

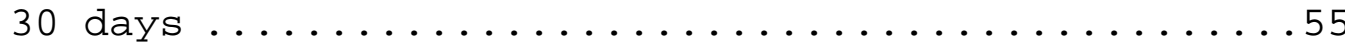

3.5 Profile plot of mean Hsp70 expression over the duration of the experiment ................56

3.6 Relative Hsp70 expression in the mantle tissue of $M$. californianus exposed to three concentrations of caffeine for 10, 20, and

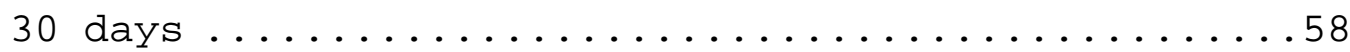




\section{CHAPTER 1: INTRODUCTION}

In the last decade, caffeine has been recognized as a ubiquitous contaminant of aquatic systems. Caffeine has been detected in rivers and lakes (Barber et. al. 1995; Kolpin et al. 2002; Boyd et al. 2003; Buerge et al. 2003; Metcalfe et al. 2003; Kim et al. 2007; Nakada et al. 2008; Rounds et al. 2009; and many others), wetlands (Peeler et al. 2006), groundwater (Seiler et al. 2009; Nakada et al. 2008; Standley et al. 2008), estuaries and bays (Siegener and Chen 2002; Peeler et al. 2006; Benotti and Brownawell 2007; Comeau et al. 2008; Ferreira 2005) and other marine systems (Weigel et al. 2002; Buerge et al. 2003; Singh et al. 2009; Knee et al. 2010). Consequently, caffeine has been described as one of the most common organic waste contaminants in natural waters (Kolpin 2002).

The most commonly cited sources of caffeine to aquatic systems (e.g. wastewater discharge, sewage spills, failing septic systems, and storm water run-off) are common inputs to marine systems; yet the occurrence and concentrations of caffeine in marine systems have been poorly documented. With the exception of estuaries and coastal bays, which have residence time and physico-chemical characteristics that differ from other marine systems, the occurrence of 
caffeine in marine systems has been the focus of only four studies.

Of these four studies, two were conducted in tropical systems (Singh et al. 2009 and knee et al. 2010) and another study collected a single set of samples from three locations in the Mediterranean Sea (Buerge et al. 2003). The most comprehensive study of the distribution of caffeine in a temperate marine system analyzed samples from 15 locations in the North sea and found caffeine to be ubiquitous in this water body (Weigel et al. 2002). No other study has documented the occurrence of caffeine across a large marine system. Therefore it is unclear whether the distribution of caffeine found in the North Sea is similar to other marine systems in temperate regions.

The Oregon Coast receives discharge from wastewater treatment plants directly and from streams and rivers draining to the coast. Elevated levels of bacteria at some Oregon beaches have been attributed to wastewater discharge and failing septic systems (Benedict and Neumann 2004). According to the Natural Resources Defense Council, 15\% of reported beach contaminations in Oregon in 2008 were due to sewage spills/leaks. These same sources that can contribute to elevated bacterial levels can also be sources of 
caffeine contamination. Despite these potential sources of caffeine, there are currently no data on the occurrence of caffeine in Oregon's coastal waters and no means to determine if caffeine poses a threat to any of the ecological communities along the Oregon Coast.

Although the concentrations of caffeine that have been reported from freshwater, estuarine, and marine systems tend to be low (in the $\mathrm{ng} / \mathrm{L}$ to low $\mu \mathrm{g} / \mathrm{L}$ range), it is possible that harmful ecological effects could occur at existing concentrations of caffeine. Conventional toxicity tests suggest that current levels of caffeine pose a negligible risk to aquatic organisms (Quinn et al. 2008; Moore et al. 2008). However, caffeine is a biologically active drug with many known molecular targets and some studies using less traditional assays indicate that caffeine can have effects on aquatic organisms that are missed by conventional toxicity tests (Gagne et al 2006; Pollack et al. 2009). However, the concentrations of caffeine used in these studies were 500-1200 fold greater than the highest concentration reported from a marine or estuarine system. Therefore, it remains unclear if environmentally relevant concentrations of caffeine can have sub-lethal effects on aquatic organisms. 
The goals of this thesis project were to: 1) quantify concentrations of caffeine occurring in the coastal ocean off of the Oregon coast and to determine if higher levels were correlated with proximity to caffeine pollution sources (Chapter 2); and 2) investigate the sub-lethal cellular toxicity of environmentally relevant concentrations of caffeine on Mytilus californianus, an intertidal mussel that is one of the dominant species of the Oregon Coast (Chapter 3). These are two fundamental steps in assessing the potential ecological risk posed by caffeine contamination on the Oregon Coast. 


\section{CHAPTER 2: OCCURRENCE AND CONCENTRATION OF CAFFEINE IN SEAWATER FROM THE OREGON COAST}

\section{INTRODUCTION}

The occurrence of caffeine, a biologically active drug, has been documented in marine and estuarine systems over the last decade. The studies reporting caffeine have documented low levels (ng/L to low $\mu \mathrm{g} / \mathrm{L}$ range) of caffeine primarily from estuaries, bays, and inlets, with some isolated reports from seas and coastal oceans (Table 2.1). These initial studies of caffeine in marine systems have largely focused on documenting the presence of the drug over relatively small spatial scales (e.g. in one estuary, or bay or in the vicinity of one population center), but have highlighted the fact that caffeine may persist in marine waters. Despite these research efforts, it remains unclear whether caffeine is a ubiquitous contaminant of marine systems and if there is any trend in the distribution of caffeine relative to anthropogenic sources of caffeine contamination.

The sources of caffeine to marine systems, and to other aquatic systems, are primarily anthropogenic. Caffeine is among the most widely consumed drugs in the world (Bradley et al 2007). It is found in a variety of 
Table 2.1. The locations and concentrations of caffeine reported in seawater in previous studies. $\mathrm{ND}=$ Not detected.

\begin{tabular}{|c|c|c|c|}
\hline Location & Type of Water & Concentration Range & Source \\
\hline North Sea & Sea & $2 \mathrm{ng} / \mathrm{L}$ & Weigel et al. 2001 \\
\hline Mediterranean Sea & Sea & $\mathrm{ND}-5 \mathrm{ng} / \mathrm{L}$ & Buerge et al. 2003 \\
\hline $\begin{array}{l}\text { Hanelai Bay, Kauai, } \\
\text { Hawaii }\end{array}$ & Bay & $\mathrm{ND}-10 \mathrm{ng} / \mathrm{L}$ & Knee et al. 2010 \\
\hline North Sea & Sea & $2-16 \mathrm{ng} / \mathrm{L}$ & Weigel et al. 2002 \\
\hline $\begin{array}{l}\text { Miami River and } \\
\text { Biscayne Bay, Florida }\end{array}$ & Estuary and bay & $\begin{array}{l}\text { 22-41 ng/L (Miami River); ND-12 } \\
\text { ng/L (Biscayne Bay) }\end{array}$ & Gardinali and Zhao 2002 \\
\hline $\begin{array}{l}\text { Miami River, Key } \\
\text { Largo Harbor, and } \\
\text { Looe Key, Florida } \\
\end{array}$ & $\begin{array}{l}\text { Estuary, canal } \\
\text { system, and } \\
\text { offshore reef }\end{array}$ & $\begin{array}{lll}13-68 \mathrm{ng} / \mathrm{L} \text { (Miami River); } & 5.7-52 \\
\text { (Key Largo Harbor); ND-29 } & \text { (Looe } \\
\text { Key) } & & \\
\end{array}$ & Singh et al. 2010 \\
\hline $\begin{array}{l}\text { Boston Harbor and } \\
\text { Massachusetts Bay, } \\
\text { Massachusetts }\end{array}$ & Estuary and bay & $\begin{array}{l}5-71 \mathrm{ng} / \mathrm{L} \text { (Massachusetts Bay); } \\
140-1600 \mathrm{ng} / \mathrm{L} \text { (Boston Harbor) }\end{array}$ & Siegener and Chen 2002 \\
\hline $\begin{array}{l}\text { Tromso Sound, Norway; } \\
\text { North Atlantic/Artic } \\
\text { Ocean }\end{array}$ & $\begin{array}{l}\text { Ocean inlet; } \\
\text { Ocean (10 km } \\
\text { from coastline) }\end{array}$ & $17-87 \mathrm{ng} / \mathrm{L} ; 7-9 \mathrm{ng} / \mathrm{L}$ & Weigel et al. 2004 \\
\hline $\begin{array}{l}\text { Guanabara Bay, Rio de } \\
\text { Janeiro, Brazil }\end{array}$ & Bay & $134-147 \mathrm{ng} / \mathrm{L}$ & Ferreira 2005 \\
\hline Sarasota Bay, Florida & Enclosed Lagoon & $\mathrm{ND}-166 \mathrm{ng} / \mathrm{L}$ & Peeler et al. 2006 \\
\hline $\begin{array}{l}\text { Halifax, Pictou, and } \\
\text { Cocagne watersheds, } \\
\text { Nova Scotia, Canada }\end{array}$ & Estuary & $\mathrm{ND}-1400 \mathrm{ng} / \mathrm{L}$ & Comeau et al 2008 \\
\hline Jamaica Bay, New York & Estuary & $\mathrm{ND}-\sim 5000 \mathrm{ng} / \mathrm{L}$ & Benotti and Brownawell 2007 \\
\hline
\end{tabular}


beverages and food products and in many pharmaceutical products (Buerge et al 2003). Although caffeine is a naturally occurring alkaloid present in more than 60 plant species (Barone and Roberts 1996), caffeine-producing plants are generally limited to tropical areas. In temperate North America there are no known natural sources of caffeine (Siegener and Chen 2002; Peeler et al 2006).

Caffeine has also been isolated from the Gorgonians Echinogogia pseudossapo, Paramuricea chamaeleon, Echinomuraceae splendens as part of research investigating natural products from marine organisms (Jingyu et al. 1984; Imre et al. 1987; Parameswaran et al. 2002). Since these are isolated detections from a few voucher specimens, it is not known whether this represents a common or significant source of caffeine to marine systems. To my knowledge, no caffeine-producing organisms have been identified in the Pacific Ocean.

The primary pathways by which anthropogenic caffeine is transported to marine systems include effluent discharge from wastewater treatment plants (WWTPs), directly or via streams and rivers draining to the coast, contaminated groundwater, particularly in areas with on-site wastewater treatment systems, and storm water run-off. Of these, 
discharge from wastewater treatment plants has received the most attention, while the others are increasingly recognized as potential sources (Buerge et al. 2006; Peeler et al. 2006; Nakada et al. 2008; Rounds et al. 2009).

Some of the earliest studies in which caffeine was documented in natural waters were conducted by the United States Geological Survey (USGS) as part of a study examining the concentrations and mass transport of pesticides and organic contaminants in the Mississippi River and its tributaries (Pereira et al. 1995). The profile of caffeine in the Mississippi River and its tributaries showed that caffeine tracked the effects of population density on water quality. Peak concentrations of caffeine were measured below Minneapolis/St. Paul and St. Louis. The elevated concentrations of caffeine in the Illinois River, a tributary of the Mississippi River, were attributed to the large population in the Chicago metropolitan area.

Such caffeine contamination of natural waters was primarily attributed to discharge from wastewater treatment plants (Buerge et al. 2003). The majority of ingested caffeine is converted to one or more secondary metabolites (Tang-Liu et al 1983). A small portion (0.5-10\%) remains 
intact when excreted (Tang-Liu et al. 1983; Siegener and Chen 2002; Buerge et al. 2003). The average daily caffeine consumption per person in the U.S. has been estimated at 140 to $210 \mathrm{mg} /$ day (Gardinali and Zhao 2002; Buerge et al. 2003). Caffeinated beverages, coffee grounds and other food and pharmaceutical products that are disposed down the drain may also enter the wastewater system. Together these represent a very significant caffeine burden, particularly in heavily populated areas; but caffeine loads to natural waters from WWTP discharge are ultimately a function of both consumption of caffeine, which is dependent on population and consumption habits, and the elimination efficiency of local WWTPs (Buerge et al. 2003).

WWTPs can eliminate some of the caffeine that enters in the effluent, but the elimination efficiency can be quite variable. Removal efficiencies can vary depending on the treatment processes employed, age of the activated sludge, hydraulic retention time, environmental conditions such as temperature and light intensity, and physical properties including the adsorption capacity of compounds on sludge (Carballa et al. 2004; Lin et al. 2009). Buerge et al. (2006) reported elimination efficiencies for caffeine of $81 \%$ to $>99 \%$ in Swiss WWTPs. This is similar to 
the elimination efficiencies of $85 \%-100 \%$ reported by Lin et al. (2009) from four Taiwanese WWTPs. For U.S. WWTPS, Siegener and Chen (2002) and Benotti and Brownawell (2007) reported removal rates for caffeine of $67 \%$ in Boston Harbor, Massachusetts and 64\% in Jamaica Bay, New York.

These estimates of the removal efficiency of caffeine were based on WWTPS employing secondary treatment (e.g. biological filtration). The removal efficiency diminishes considerably in WWTPs using less advanced treatment processes. For example, Weigel et al. (2004) reported a removal efficiency of $13 \%$ in a WWTP using mechanical filtration, but not biological treatment.

Significant caffeine loading from WWTPs can also occur from combined sewer overflows (CSO) or sewage spills regardless of removal efficiencies during normal WWTP operation. For example, Buerge et al. (2003) found a 4 to 5 fold discrepancy between measured caffeine concentrations in Swiss Midland lakes and estimates based on local population and consumption habits and the elimination efficiencies of WWTPs in the area. The discrepancies were attributed to untreated sewage inputs from CSOs that enter the lake during storm events. In a subsequent study, Buerge et al. (2006) estimated that even a small percentage of 
untreated wastewater could considerably increase the load of caffeine to receiving waters. They concluded that caffeine could be a good organic tracer of CSOs in areas where WWTPs have high elimination efficiencies during normal operations, but not if elimination efficiencies were low.

The fact that caffeine is not a good tracer of cso events in areas where WWTPs have low elimination efficiencies has been demonstrated. In Jamaica Bay, New York, Benotti and Brownawell (2007) found that caffeine concentrations decreased following heavy precipitation that induced CSOs, compared to concentrations during dry weather conditions. This observation was consistent with the expected behavior of compounds with poor eliminations efficiencies that are diluted by the heavy precipitation that causes CSOs. In contrast, the concentration in the receiving water body of compounds that normally had high elimination efficiencies increased following a CSO because the treatment process was by-passed.

other pathways by which caffeine can enter marine systems include groundwater discharge and storm water runoff. Caffeine contaminated groundwater can discharge into marine systems as was shown by Peeler et al. (2006) in 
Sarasota Bay, Florida. Caffeine in groundwater can originate from leaking sewer lines (Nakada et al. 2008) or from the leachate of on-site wastewater treatment systems, particularly in communities that rely heavily on on-site systems (Buerge et al. 2006; Peeler et al. 2006). Similar to WWTPs, the removal efficiency of on-site wastewater treatment systems can vary depending on the type of treatment employed (e.g. biofilters or sand filters). Matamoros et al. (2009) tested four types of on-site wastewater treatment systems and reported mean removal efficiencies ranging from 67-99\%. This does not account for failing or poorly maintained on-site systems that presumably have reduced elimination efficiencies, although this has not been systematically tested.

Storm water run-off has only very recently been recognized as a source of caffeine to water bodies. In one of the only studies to account for this source of caffeine, Rounds et al. (2009) cautioned that caffeine might be present in streams as a result of people discarding coffeecup residue on the street. They estimated that in Fanno Creek, Oregon, which has typical flows of $4 \mathrm{ft}^{3} / \mathrm{s}$, the measured caffeine concentration of $0.01 \mu \mathrm{g} / \mathrm{L}$ represents a spill of only 1 ounce of coffee residue that is completely 
mixed into the stream every 2.5 hours. Since caffeine entering the storm water system is not removed (except where the sewer and storm water systems are combine and when the system capacity is not exceeded), storm water could represent a significant source of caffeine to aquatic systems, including marine systems. A comparison of estimated caffeine loads from WWTP effluent and storm water has not been done.

Despite the fact that marine systems receive wastewater and storm water discharge, directly and via streams that discharge to the coastal ocean, and that many coastal communities rely on on-site wastewater treatment systems, there is a relative paucity of information on the occurrence and distribution of caffeine in marine systems. The majority of the studies reporting caffeine from marine systems have been conducted in estuaries or coastal bays near a major metropolis (Siegener and Chen 2002; Gardinali and Zhao 2002; Ferreira 2005; Peeler et al. 2006; Benotti and Brownawell 2007; Comeau et al 2008). Additional information is needed to better understand the patterns of caffeine contamination in different types of marine systems . 
Due to the low concentrations of caffeine reported from estuaries and bays receiving waste discharge from large population centers, caffeine contamination in open coastal waters, where contaminant plumes could ostensibly experience rapid mixing and extensive dilution, might be expected to be negligible. However, recent work has shown that surf zone entrainment and along-shore transport of pollution can be significant (Grant et al. 2005). Furthermore, the environmental conditions (temperature, salinity, pH, microbial activity) in open coastal waters may lead to the enhanced stability of contaminants such as caffeine (Weigel et al. 2001). Therefore, nearshore coastal waters may actually be susceptible to caffeine contamination.

The Oregon Coast receives discharge from wastewater treatment plants directly and from streams and rivers draining to the coast. Elevated levels of bacteria at some Oregon beaches have been attributed to wastewater discharge and failing septic (Benedict and Neumann 2004). According to the Natural Resources Defense Council, 15\% of reported beach contamination events in Oregon in 2008 were due to sewage spills/leaks. The same sources that can contribute to elevated bacterial levels can also be sources of 
caffeine contamination. Despite these potential sources of caffeine, there are currently no data on the occurrence of caffeine in Oregon's coastal waters.

The primary goal of this study was to provide a preliminary survey of caffeine concentrations in nearshore open coastal waters along the Oregon Coast, and to examine correlation with human population centers. The research presented in this chapter provides new information on the distribution of caffeine in open coastal waters. The study addressed the following questions:

- Is caffeine commonly detected in the coastal ocean off of the Oregon Coast?

- Is caffeine found at background levels throughout the Oregon Coast or are there signals from developed areas?

- How do the concentrations of caffeine in Oregon's coastal ocean compare to water bodies draining into the ocean?

\section{METHODS}

Sampling Location Selection

Fourteen coastal ocean locations were sampled along the Oregon Coast, from Astoria in the north to Brookings in the South. Sampling locations were evenly stratified between two categories: 1) populated areas with pollution threats (point and non-point sources) and 2) sparsely 
populated areas with no identifiable pollution threats. A definition of the criteria used to select sites in populated areas with pollution threats is provided in Table 2.2. In addition, for each of the ocean sampling locations that had pollution threats, the major river discharging near that location was also sampled.

The criteria for site selection were adopted from the United State Environmental Protection Agency (USEPA) standards used to select Oregon's beach sites for application to the USEPA'S BEACH Act (Benedict and Neumann 2004). These standards are based on the distance from a WWTP or stream that is potentially impacted by each pollution source.

Table 2.2. Criteria used to select sampling locations with caffeine pollution threats.

\begin{tabular}{|c|c|}
\hline Pollution threats & Criteria \\
\hline Population & $\begin{array}{l}\text { Located within the boundary of one of } \\
\text { the seven most populated costal cities } \\
\text { in Oregon }\end{array}$ \\
\hline sources & $\begin{array}{l}\text { Wastewater treatment plant (WWTP) } \\
\text { within } 5 \text { miles }\end{array}$ \\
\hline Non-point sources & River or stream within $1 / 2$ mile \\
\hline
\end{tabular}

Criteria for sampling location selection were evaluated using GIS (ArcGIS 9.2). The base layers, listed in Table 2.3, were downloaded from the Oregon Geospatial Enterprise Office (http://www.GIS.Oregon.gov). The base 
layers were clipped to the seven counties that border the Oregon Coast. These seven counties are Clatsop, Tillamook, Lincoln, Lane, Douglas, Coos, and Curry Counties. A query definition was built for the clipped Oregon Water Bodies layer so that only streams, rivers, and estuaries were active (i.e. lakes and reservoirs were excluded).

The Oregon Department of Environmental Quality Profiler (http://deq12.deq.state.or.us/fp20) was used to identify all wastewater treatment plants (WWTPs) located within the seven coastal counties. This information was exported as a .CSV file and the latitude/longitude used to create a layer of WWTPs.

Table 2.3. Base layers used $\mathrm{n}$ the GIS analysis for selecting sampling locations.

Layer

Source

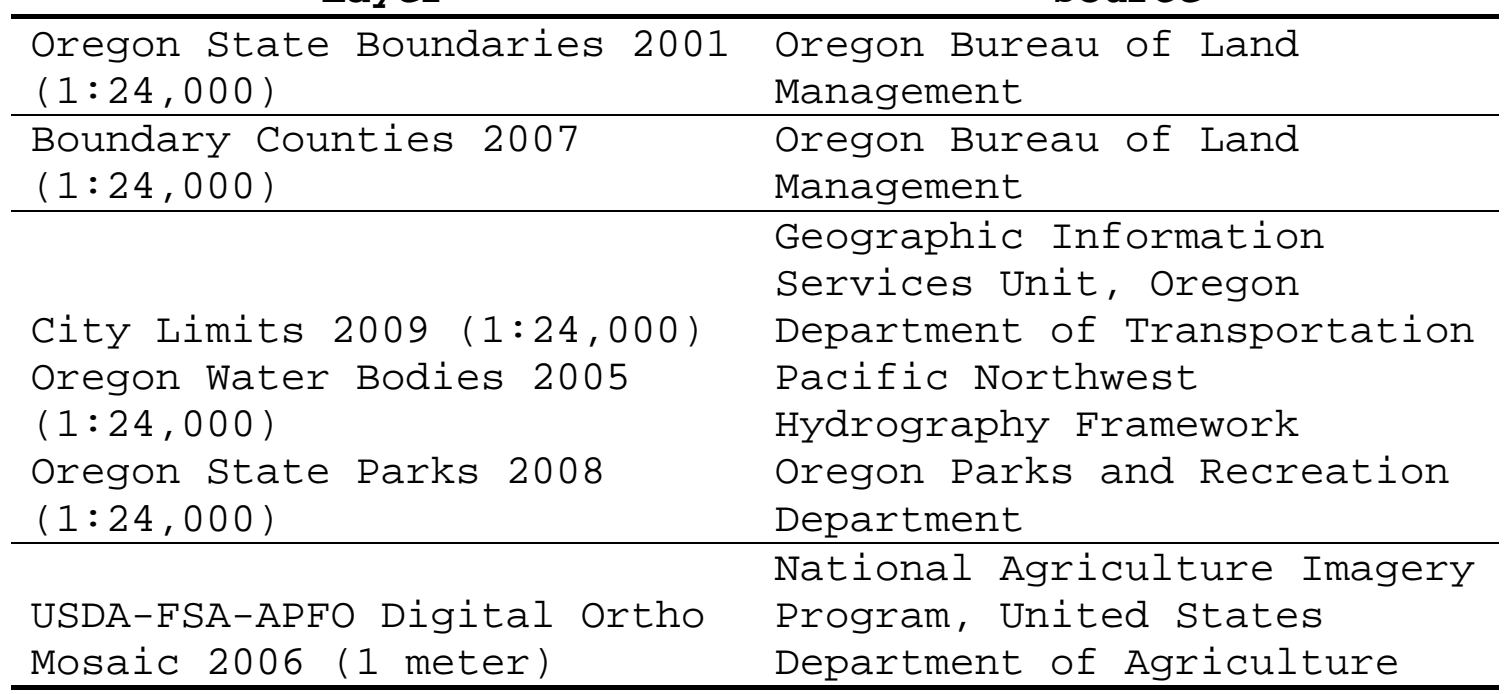


The seven largest population centers were identified using the population attribute in the City Limits layer. Three areas were identified where two or more cities were next to each other. These areas were Astoria/Warrington, Coos Bay/North Bend, and Seaside/Gearhart. For the purposes of the analysis these were treated as one area. The seven most populated areas in the Oregon Coast and their population are listed in Table 2.4 .

Potential sampling locations were identified by creating a 5-mile buffer around the features in the WWTPs layer and a $1 / 2-m i l e$ buffer around the features Oregon water Bodies layer that were within the seven most populated areas along the Oregon Coast. Areas with the most potential pollution impact from point and non-point sources were identified by creating an intersection of the WWTPs and Oregon Water Bodies buffer and of the City Limits layer.

Table 2.4. The seven most populated areas in the Oregon coast with populations from the Oregon 2000 Census Data.

\begin{tabular}{lrr}
\hline City (Rank) & $\begin{array}{c}\text { Population } \\
\text { (From Oregon census data 2000) }\end{array}$ \\
\hline Coos Bay/North Bend (1) & & 24918 \\
\hline Astoria/Warrington (2) & 13909 \\
\hline Newport (3) & 9532 \\
\hline Lincoln City (4) & 7437 \\
\hline Florence (5) & 7263 \\
\hline Seaside/Gearhart (6) & 6895 \\
\hline Brookings (7) & 5447 \\
\hline
\end{tabular}


Final sampling locations were selected from the potential sampling areas after visual inspection of satellite imagery to ensure that the area had public access to the ocean. A sampling location with public access was similarly identified for the major river discharging within $1 / 2$ mile of each of the selected ocean sampling locations. To ensure that the river sampling location was downstream of the pollution impacts in the area, a sample from the estuarine area of the river had to be collected in some instances, as reflected in the salinity measurements.

Potential sampling locations in sparsely populated areas with no identifiable pollution threats were selected by querying the Oregon state Parks layer for parks with public access to the ocean that were outside the intersection of the WWTPs, the Oregon Water Bodies buffer and the City Limits layer. Final sampling locations that were as far as possible from a city or other development were selected from the potential locations.

A list of the final sampling locations that were selected is provided in Table 2.5. Figure 2.1 and Figure 2.2 shows the sampling locations located along the North and South Oregon Coast, respectively. 
Chemicals

Caffeine (Fluka Analytical, $1.0 \mathrm{mg} / \mathrm{mL} \pm 5 \%$ in methanol) and ${ }^{13} \mathrm{C}_{3}$-labeled caffeine (Fluka Analytical, $1 \mathrm{mg} / \mathrm{ml}$ in methanol, 99\% purity) were purchased from Sigma-Aldrich. ${ }^{13} \mathrm{C}_{3}$-labeled caffeine was used as a surrogate standard to determine recovery rates. Solvents used for sample preparation were either ACS reagent grade or Optima grade (ultra high purity) from Fisher Scientific.

Table 2.5: Selected sampling locations listed from north to south and pollution threat (waste water treatment plants, high population, and proximity to caffeinated stream).

\begin{tabular}{ll}
\hline Name & Pollution Threats \\
\hline Astoria/Warrenton & Yes \\
\hline Seaside/Gearhart & Yes \\
\hline Cape Lookout & No \\
\hline Lincoln City & Yes \\
\hline Newport & Yes \\
\hline Carl Washburne & No \\
\hline Florence & Yes \\
\hline Siltcoos & No \\
\hline Horsfall & No \\
\hline Coos Bay/North Bend & Yes \\
\hline Seven Devils & No \\
\hline Cape Blanco & No \\
\hline Ophir Beach & No \\
\hline Brookings & Yes \\
\hline
\end{tabular}




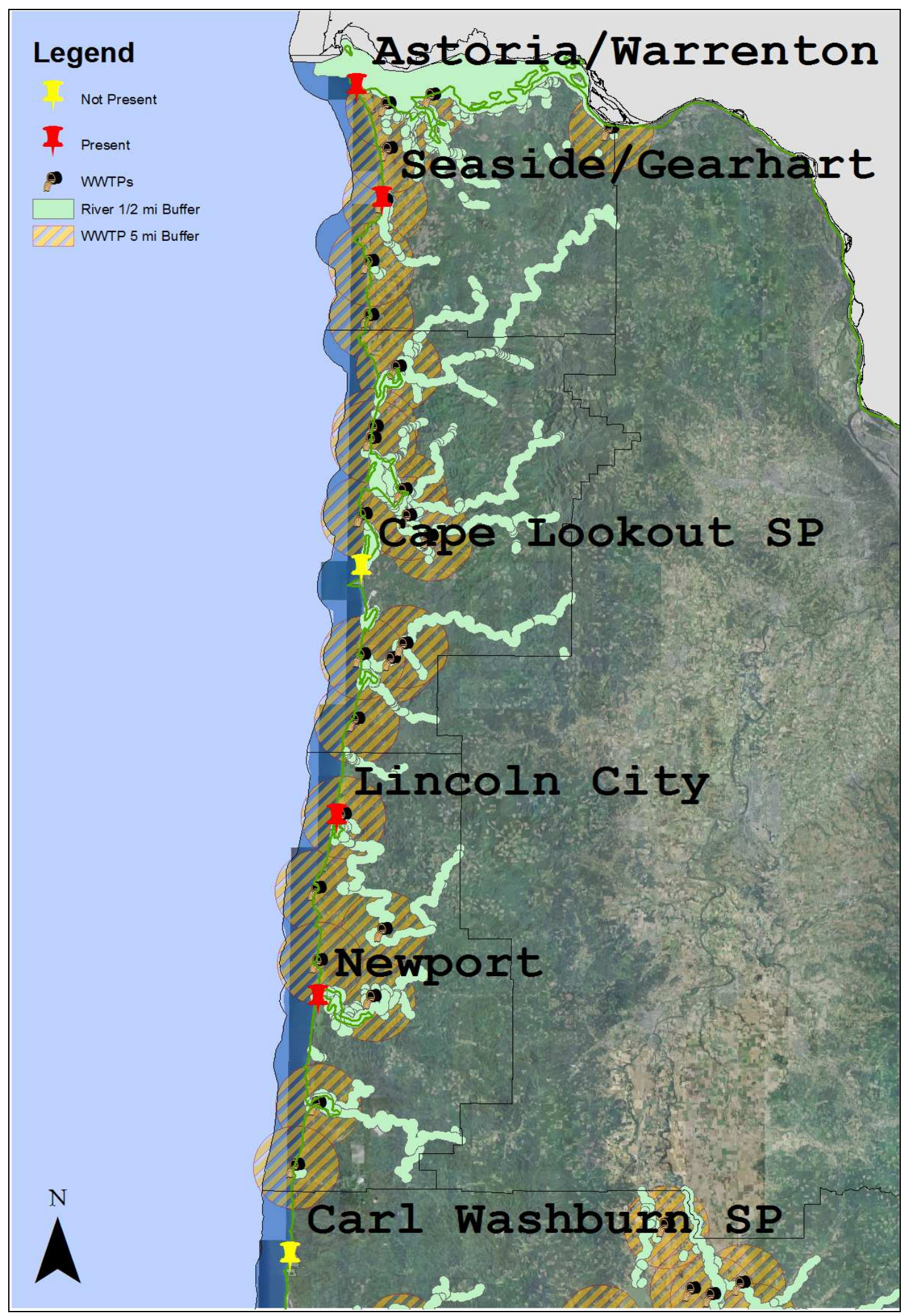

Figure 2.1: Final sampling locations in the North Oregon Coast showing the location of WWTPs and the WWTP and stream buffers used in the GIS analysis. 


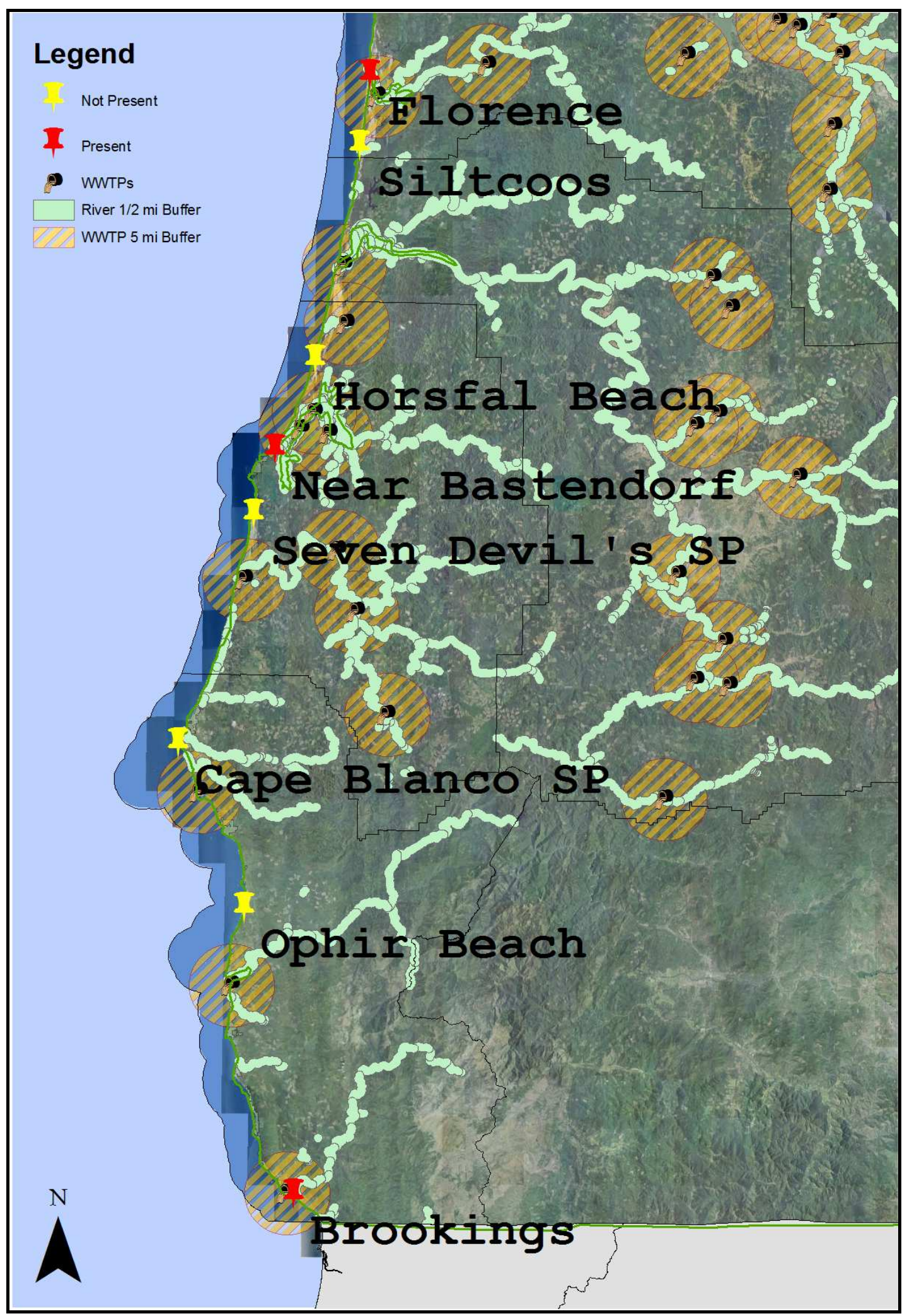

Figure 2.2: Final sampling locations in the South Oregon Coast showing the location of WWTPs and the WWTP and stream buffers used in the GIS analysis. 
Sample Collection

Sea and river water samples were collected in 1-L amber bottles (Fisher Scientific) from the surf zone and off the river channel bank, respectively. Bottles and caps were rinsed six times with sample water. The bottles were submerged $38 \mathrm{~cm}$ below the water surface, filled to capacity, and immediately capped underwater. Samples were kept on ice and in the dark in a cooler until extracted (within 24 hours). Salinity at each sampling location was measured using a hand-held meter (YSI 55). There are currently no standard methods for collecting water samples for caffeine analysis. However, due to the ubiquity of caffeine, precautionary methods to minimize the risk of inadvertent sample contamination are common practice. To minimize the risk of sample contamination, sample collectors abstained from all caffeinated products (e.g. coffee, tea, energy drinks) beginning 24 hours prior to sample collection and throughout sample preparation. While collecting or preparing samples, sample collectors wore standard respirators and fresh latex gloves. 
$\underline{\text { Sample Preparation }}$

Extraction was done using ENVI-Carb, solid phase
extraction (SPE) disposable tubes (Supelclean, graphitized
nonporous carbon, bed wt. $250 \mathrm{mg}, 6 \mathrm{ml}$ volume) according to
manufacturer's instructions. ENVI-Carb SPE tubes have
extreme affinity for organic polar and non-polar compounds
from polar matrices. Prior to use, the tubes were rinsed
with 5 ml of dichloromethane (ACS reagent grade) and then
conditioned with 5 ml of methanol (ACS reagent grade) and
lo ml of nanopure water.

Samples were decanted to $1 \mathrm{~L}$ and fortified with ${ }^{13} \mathrm{C}_{3}-$ labeled caffeine to a concentration of $50 \mathrm{ng} / \mathrm{L}$. The ${ }^{13} \mathrm{C}_{3}-$ labeled caffeine was used as a surrogate for caffeine to estimate sample recovery and correct for any losses from sample processing. 1 L sample was passed through a GF/C glass microfibre filter (Whatman, particle retention $1.2 \mu \mathrm{m}$ ) mounted on to a Swinnex filter holder and then the SPE tube at approximately $5 \mathrm{ml} / \mathrm{min}$. After the sample was extracted, the tubes were washed with $5 \mathrm{ml}$ of nanopure water and then dried for approximately 5 minutes. The tubes were then washed with $5 \mathrm{ml}$ of methanol (ACS reagent grade) to remove any remaining water. Prior to sample preparation, methanol 
was tested to ensure that this solvent did not remove any caffeine from the SPE tubes.

The analytes were recovered with $10 \mathrm{ml}$ of dichloromethane (Optima grade) into a glass vial. The dichloromethane extract was reduced to dryness in a gentle hot water bath at a temperature below the boiling point of dichloromethane (at approximately $20^{\circ} \mathrm{C}$ ). The residue was then brought to a final volume of $100 \mu \mathrm{L}$ using dichloromethane (Optima grade).

$\underline{\mathrm{GC}-\mathrm{MS}-\mathrm{SIM}}$

Aliquots of $1 \mu \mathrm{L}$ of the final extract were analyzed by $\begin{array}{lll}\text { gas chromatography-mass spectrometry (GC-MS). GC-MS } & \text { G }\end{array}$ analysis was performed using an Agilent 5975C Gas Chromatographer with a Mass Selective Detector. The column used was HP-5MS (5\% phenyl methyl silox, $30 \mathrm{~m}$ x $250 \mu \mathrm{m} x$ $0.25 \mu \mathrm{m})$. The injection was splitless and the carrier gas was helium (purity 99.999\%). All samples where run at least twice to verify the stability of the instrument response. The analytical conditions are summarized in Table 2.6 and a sample GC-MS chromatogram and mass spectrum is presented in Figure 2.3. 
Table 2.6: Summary of GC-MS analytical conditions

\section{GC analytical conditions}

\begin{tabular}{|c|c|}
\hline Carrier gas: & Helium \\
\hline $\begin{array}{l}\text { Oven temperature } \\
\text { program: }\end{array}$ & $\begin{array}{l}\text { Initial temperature } 60{ }^{\circ} \mathrm{C}(2 \mathrm{~min}) \\
15{ }^{\circ} \mathrm{C} / \mathrm{min} \text { to } 250{ }^{\circ} \mathrm{C}(10 \mathrm{~min}) \\
\text { Then } 10{ }^{\circ} \mathrm{C} / \mathrm{min} \text { to } 300{ }^{\circ} \mathrm{C}(3 \mathrm{~min}) \\
\text { Final Temperature } 300{ }^{\circ} \mathrm{C} \\
\text { Run Time } 20 \mathrm{~min}\end{array}$ \\
\hline Injection mode: & Splitless \\
\hline Injector temperature: & $220^{\circ} \mathrm{C}$ \\
\hline Total flow: & $51.93 \mathrm{ml} / \mathrm{min}$ \\
\hline Septum purge flow: & $1 \mathrm{ml} / \mathrm{min}$ \\
\hline \multirow[t]{2}{*}{ Column: } & HP-5MS (5\% phenyl methyl silox) \\
\hline & $30 \mathrm{~m} \times 250 \mathrm{um} \times 0.25 \mathrm{um}$ \\
\hline \multicolumn{2}{|c|}{ MS analytical conditions } \\
\hline Solvent delay & $6 \mathrm{~min}$ \\
\hline $\begin{array}{l}\text { MS transfer line } \\
\text { temperature: }\end{array}$ & $230{ }^{\circ} \mathrm{C}$ \\
\hline EMV Mode & Absolute \\
\hline EMV Voltage & 1400 \\
\hline \multirow[t]{2}{*}{ SIM mode ions: } & Caffeine $194,109,82$ \\
\hline & 13C3-labeled caffeine 197 \\
\hline
\end{tabular}

Analytes were quantified in the SIM mode using the most intensive ions, $\mathrm{m} / \mathrm{z} 194$ for caffeine and 197 for ${ }^{13} \mathrm{C}_{3}-$ labeled caffeine. Caffeine identification was confirmed by GC retention time and two qualifier ions (m/z 82 and 109). A sample chromatogram with the ions 194 and 197 overlaid is shown in Figure 2.4. The amount of caffeine and ${ }^{13} \mathrm{C}_{3}-$ labeled caffeine in each sample was determined from the peak area of the 194 and 197 ions compared to standard calibration 
solutions. Five concentrations each of caffeine and ${ }^{13} \mathrm{C}_{3}-$ labeled caffeine were used for the calibration standards $(0.01,0.05,0.1,0.5$ and $1 \mathrm{ng} / \mu \mathrm{L})$. Final sample caffeine concentrations were adjusted for recovery rates of ${ }^{13} \mathrm{C}_{3}-$ labeled caffeine. Samples showed acceptable recoveries of $37-136 \%($ mean $=78 \%, S \cdot D .=20 \%)$.

$\underline{Q A / Q C}$

Quality assurance samples were analyzed in runs with samples and included field blanks, method blanks, and check standards. Field blanks were prepared with nanopure water in the laboratory and traveled in the cooler with the water samples. Handling and sample preparation was identical for field blanks and samples. A total of six blanks were analyzed. Caffeine concentrations in nanopure water (blank) were $2.5 \mathrm{ng} / \mathrm{L}$ (S.D. $=2.0 \mathrm{ng} / \mathrm{L})$. The reporting limit for caffeine was adjusted to account for blank detection. The adjusted reporting limit was determined by adding three times the standard deviation to the mean blank caffeine concentration (8.5 ng/L) following Standley et al.(2008). 

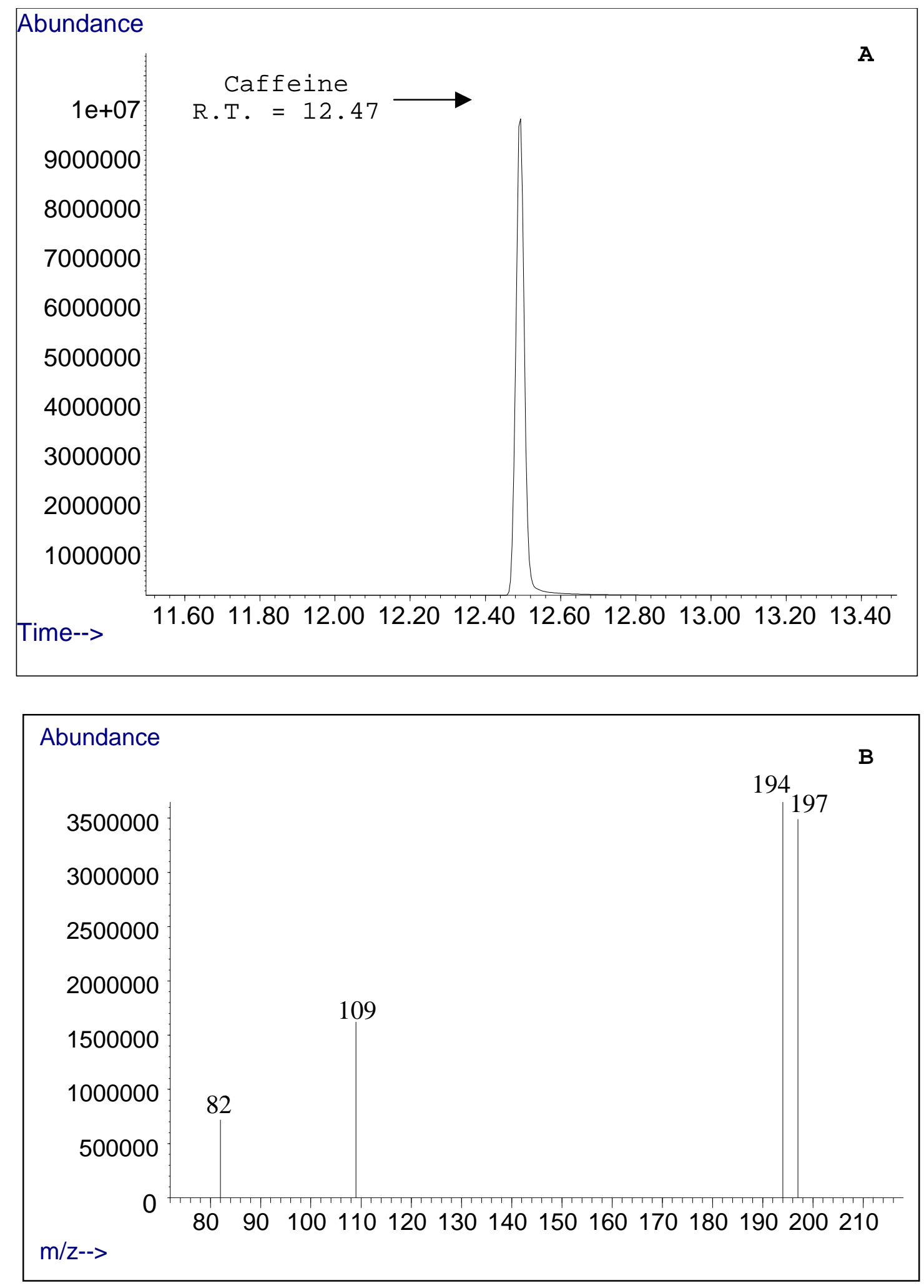

Figure 2.3. Sample A) chromatograms and B) mass spectrum for a 5 ng/uL standard solution run in SIM mode. 


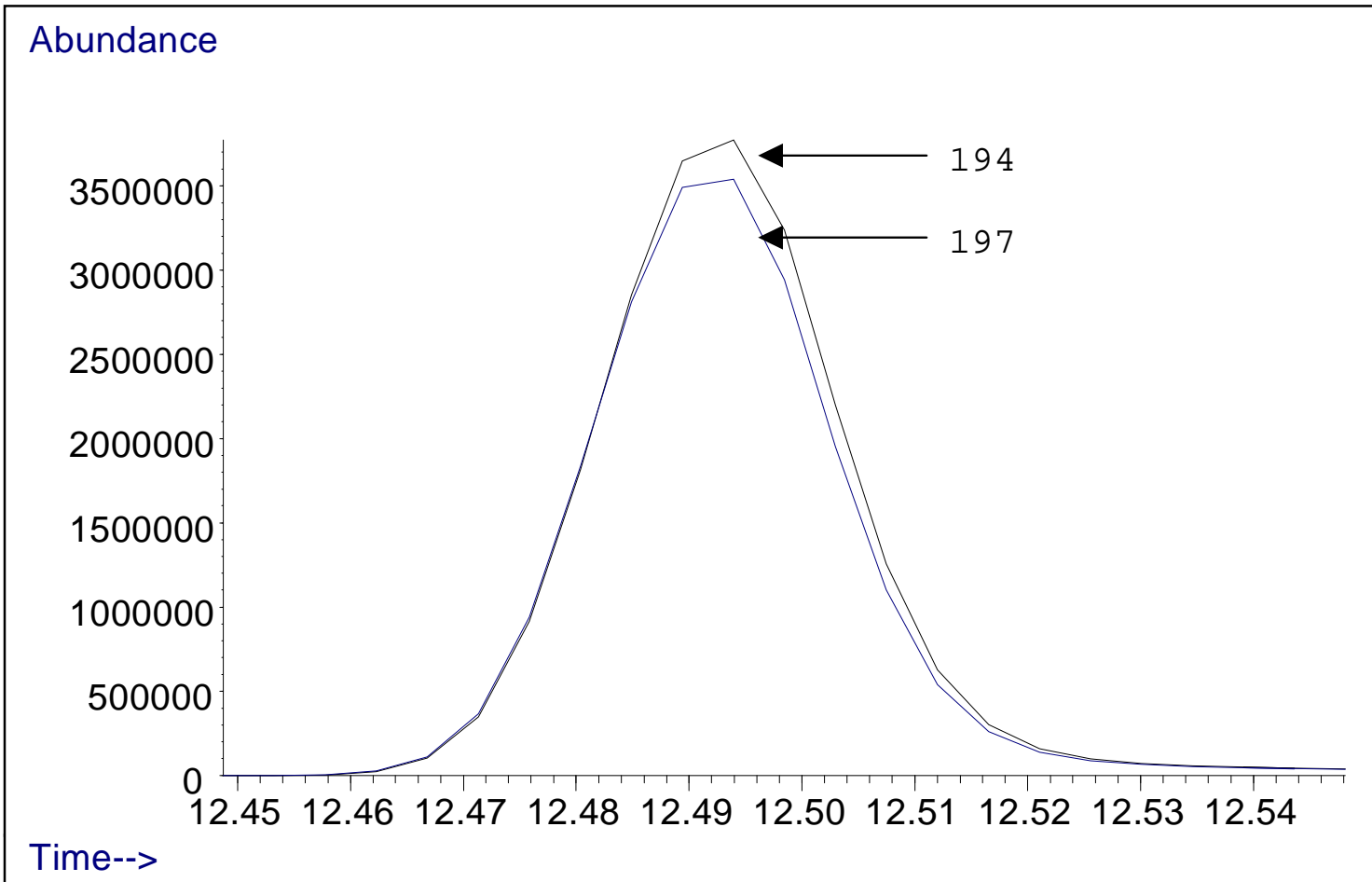

Figure 2.4. Sample chromatogram of a $5 \mathrm{ng} / \mathrm{L}$ standard solution with the quantifier ions for caffeine and ${ }^{13} \mathrm{C}_{3}-$ labeled caffeine overlaid (ions 194 and 197).

\section{RESULTS}

Of the twenty-one water samples, including 14 from the coastal ocean and 7 from adjacent water bodies, analyzed for caffeine, nine samples contained caffeine above the reporting limit $(8.5 \mathrm{ng} / \mathrm{L})$. The nine samples included 5 ocean samples and 4 freshwater samples.

Despite the scrupulous methods used to avoid sample contamination, field blanks contained low levels of caffeine. Five of the six field blanks had concentrations of 1.6 to $1.9 \mathrm{ng} / \mathrm{L}$, and one blank had $6.6 \mathrm{ng} / \mathrm{L}$. 
Samples from the coastal ocean had caffeine concentrations ranging from below the reporting limit to $44.7 \mathrm{ng} / \mathrm{L}$ (Table 2.7). The occurrence and concentrations of caffeine in the coastal ocean did not correspond well with pollution threats from population density and potential point and non-point sources. Coastal ocean samples from Coos Bay/North Bend and Astoria/Warrenton, two of the most populated areas on the Oregon coast, both had caffeine concentrations below the reporting limit. Caffeine concentrations in seawater samples from Carl Washburne and Cape Lookout, two areas identified as not being in the immediate vicinity of pollution threats, had the highest levels of caffeine measured in any of the coastal ocean samples (Table 2.7).

With the exception of a sample taken from the seawater in the Astoria/Warrenton area, all river and coastal ocean samples collected from the North Oregon Coast (Astoria/Warrenton to Carl Washburne) on April 3, 2010 had detectable levels of caffeine. All river and coastal ocean samples collected on April 9, 2010 from the South Oregon coast (Florence to Brookings) were below the detection limit. On April 2, 2010, the day prior to the collection of samples from the North Oregon Coast, an unusual late-season 
storm brought heavy rainfall, strong winds, and heavy surf to the northern coast of Oregon. This storm and associated rainfall likely influenced the higher levels of caffeine observed along the North Oregon Coast.

Samples from water bodies adjacent to coastal ocean sampling locations had caffeine concentrations ranging from below the reporting limit to $152.2 \mathrm{ng} / \mathrm{L}$ (Table 2.7). Caffeine measured at coastal ocean sampling locations in the North Oregon Coast exhibited a strong negative correlation (Pearson's R=0.92, p-value <0.05) with concentrations measured in adjacent water bodies (Figure 2.5). Samples collected from the South Oregon Coast were not included in this analysis because caffeine concentrations were below the reporting limit. 


\begin{tabular}{|c|c|c|c|c|c|c|}
\hline Name & $\begin{array}{l}\text { Caffeine } \\
(\mathrm{ng} / \mathrm{L})\end{array}$ & $\begin{array}{l}\text { Salinity } \\
\text { (PSU) }\end{array}$ & $\begin{array}{l}\text { Pollution } \\
\text { Threats }\end{array}$ & $\begin{array}{l}\text { Adjacent } \\
\text { River }\end{array}$ & $\begin{array}{l}\text { Caffeine } \\
\text { (ng/L) }\end{array}$ & $\begin{array}{l}\text { Salinity } \\
\text { (PSU) }\end{array}$ \\
\hline $\begin{array}{l}\text { Astoria/ } \\
\text { Warrenton }\end{array}$ & $<\mathrm{MRL}$ & 22.0 & Yes & $\begin{array}{l}\text { Columbia } \\
\text { River } \\
\text { Estuary }\end{array}$ & 152.2 & 2.4 \\
\hline $\begin{array}{l}\text { Seaside/ } \\
\text { Gearhart }\end{array}$ & 9.2 & 20.0 & Yes & $\begin{array}{l}\text { Necanicum } \\
\text { River }\end{array}$ & 91.0 & 2.5 \\
\hline Cape Lookout & 44.7 & 23.5 & No & & & \\
\hline Lincoln City & 18.1 & 26.4 & Yes & $\begin{array}{l}\text { Siletz } \\
\text { River } \\
\text { Estuary }\end{array}$ & 11.3 & 14.3 \\
\hline Newport & 18.2 & 25.9 & Yes & $\begin{array}{l}\text { Yaquina } \\
\text { River } \\
\text { Estuary }\end{array}$ & 66.9 & 17.1 \\
\hline Carl Washburne & 29.7 & 23.7 & No & & & \\
\hline Florence & $<\mathrm{MRL}$ & 25.3 & Yes & $\begin{array}{l}\text { Siuslaw } \\
\text { River } \\
\text { Estuary }\end{array}$ & $<\mathrm{MRL}$ & 5.8 \\
\hline Siltcoos & $<\mathrm{MRL}$ & 29.5 & No & & & \\
\hline Horsfall & $<\mathrm{MRL}$ & 29.6 & No & & & \\
\hline Coos Bay/North & $<\mathrm{MRL}$ & 29.3 & Yes & $\begin{array}{l}\text { Coos Bay } \\
\text { Estuary }\end{array}$ & $<\mathrm{MRL}$ & 20.1 \\
\hline Seven Devils & $<\mathrm{MRL}$ & 29.6 & No & & & \\
\hline Cape Blanco & $<\mathrm{MRL}$ & 29.3 & No & & & \\
\hline Ophir Beach & $<\mathrm{MRL}$ & 28.3 & No & & & \\
\hline Brookings & $<\mathrm{MRL}$ & 27.3 & Yes & $\begin{array}{l}\text { Chetco } \\
\text { River }\end{array}$ & $<\mathrm{MRL}$ & 0.3 \\
\hline
\end{tabular}




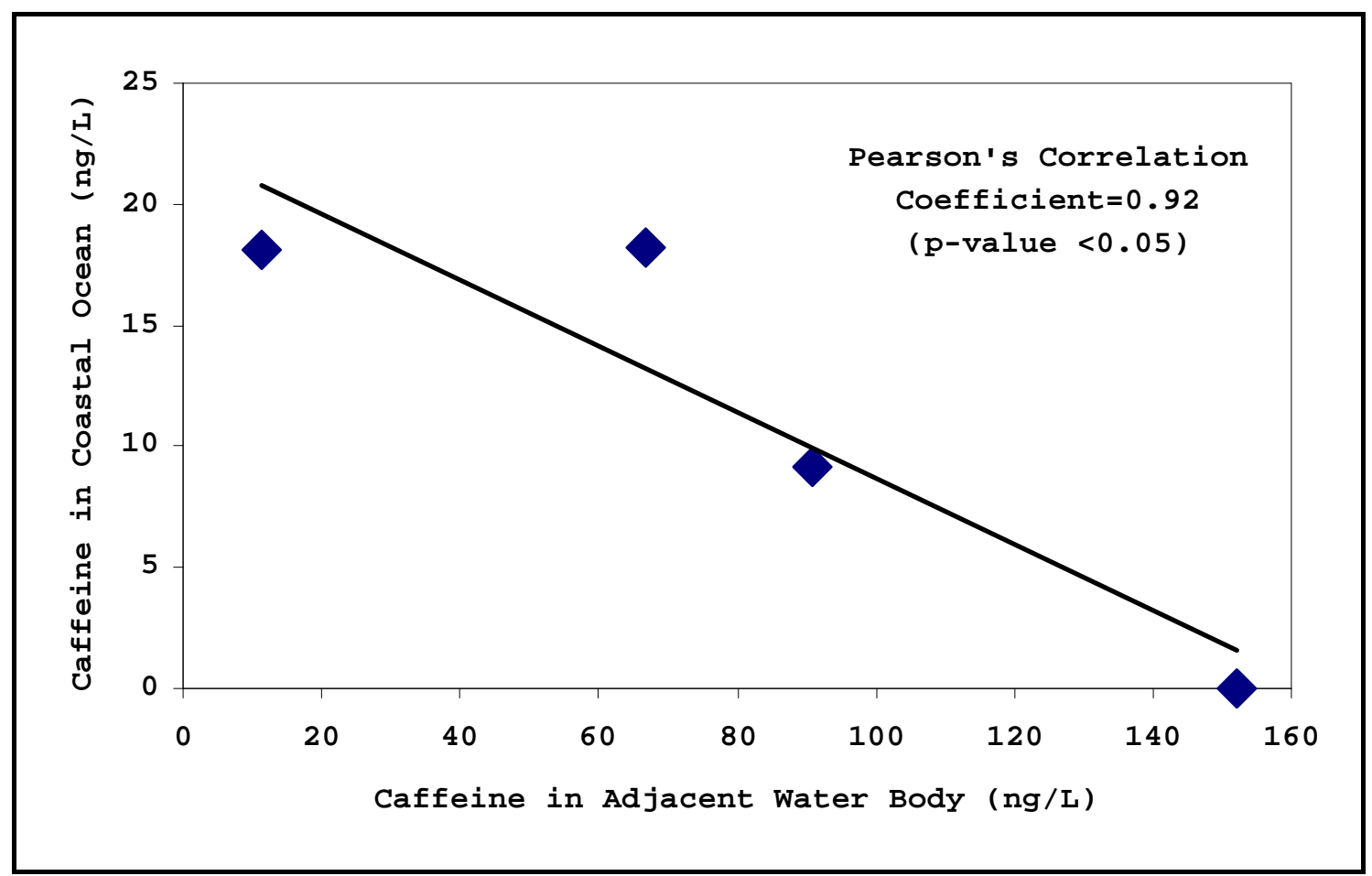

Figure 2.5: Relationship between caffeine measured in coastal ocean samples and adjacent water bodies.

\section{DISCUSSION}

This study provides a snapshot of the distribution of caffeine along the Oregon Coast. Caffeine was detected in coastal ocean water from several locations along the Oregon Coast, verifying that caffeine can be a contaminant in the coastal ocean off of the Oregon Coast. Notably, reportable levels of caffeine were only detected in the North Oregon Coast post a large, late-season storm, but not from samples collected one week later from the South Oregon Coast.

The concentrations of caffeine encountered in the coastal ocean ranged from below the reporting limit to 44.7 
ng/L. These concentrations are similar to caffeine concentrations reported in previous studies from other open ocean marine systems (Table 2.1). Higher caffeine concentrations have been reported in other types of marine systems, but these were from enclosed water bodies (e.g. estuaries and bays) in highly populated areas (Siegener and Chen 2002; Peeler et al. 2006; Benotti and Brownawell 2007) or from areas near wastewater discharge (Comeau et al 2008). Higher caffeine concentrations than found in this study may be present in the coastal ocean off of the Oregon Coast during combined sewer overflows, raw or partially treated sewage spills, or near the outfalls of wastewater treatment plants that discharge directly into the ocean. This study did not directly target these events or the areas near WWTP outfalls.

One of the main aims of this study was to investigate the relationship between caffeine concentrations in the coastal ocean and pollution threats from population density and potential point and non-point sources. Pereira et al. (1995) reported that in the Mississippi River and its tributaries caffeine tracked the effects of population density on water quality. A similar pattern of caffeine distribution could be reasonably expected in the coastal 
ocean off the Oregon Coast since sources of caffeine are anthropogenic. In one of the few studies to investigate the distribution of caffeine in a marine system over a large scale, Weigel et al. (2002) found that caffeine was ubiquitous in the North Sea, but this finding has not been validated in another region.

Caffeine concentrations in the coastal ocean off of the Oregon Coast were not found to correspond well with pollution threats from population density and potential point and non-point sources. The highest levels of caffeine were detected at two of the locations identified as not being in the immediate vicinity of pollution threats. Neither was caffeine found to be a ubiquitous contaminant in the coastal ocean off of the Oregon Coast, as was reported in the study from the North Sea. Samples from nine of the fourteen coastal ocean locations were below the reporting limit for caffeine, including samples from the two most populated areas on the Oregon Coast (Coosbay/North Bend and Astoria/Warrenton).

This study, however, provided anecdotal evidence that along the Oregon coast caffeine contamination of the coastal ocean may be associated with storm events. All coastal ocean and river samples collected from the North 
Oregon Coast on April 3, 2010, with the exception of the costal ocean sample collected from the Astoria/Warrenton area, had a caffeine concentration above the reporting limit. On April 2, 2010 there was an unusual late-season storm event that brought heavy rainfall to the oregon Coast. In contrast, all samples collected from the south Oregon Coast on April 9, 2010, one week after the storm event, had caffeine concentrations below the reporting limit.

Storm events can be associated with CSO events and may also mobilize other sources of caffeine, such as septic tank leachate and storm water. Although the elimination efficiency of caffeine for many WWTPs can be quite high (Buerge et al. 2006; Lin et al. 2009), during wet-weather conditions WWTPs may not achieve the same effluent quality if total flow exceeds the treatment capacity resulting in increased caffeine delivery to receiving waters (Buerge et al. 2006; Benotti and Brownawell 2007). The behavior of other transport pathways (e.g. septic tank leachate and storm water run-off) during wet-weather conditions are poorly understood, but could also increase the caffeine burden to receiving waters. 
The sources of caffeine that were mobilized as a result of the April 2 storm are not known, since this study did not attempt to quantify the contribution of different sources of caffeine to the coastal ocean. The concentration of caffeine in rivers adjacent to coastal ocean sampling locations was measured as part of this study. River discharge represents one non-point source of caffeine to the coastal ocean. Interestingly, an inverse relationship was found between caffeine concentrations in coastal ocean locations and adjacent rivers and the highest caffeine concentrations were found at two locations (Cape Lookout SP and Carl Washburne SP) that do not have river discharge in the vicinity.

The transport and fate of materials discharged by rivers is related to the patterns and dynamics of river plumes during discharge events (Warrick et al. 2004). Recent work has shown that river water and constituents can be delivered rapidly to coastal waters kilometers away from river mouths (Warrick et al. 2004; Washburne et al. 2003; Warrick et al. 2007). Surf zone entrainment and along-shore transport of pollution from river plumes has been shown to be significant (Grant et al. 2005). Similar dynamics have also been shown for the plumes of sewage outfalls 
discharging to the ocean (Sun and Tao 2004). Therefore, as suggested by Warrick et al. (2004 and 2007), water quality impacts from outflow of a watershed may be exhibited in portions of the coastal ocean far from the source watershed.

Such a phenomenon might explain the distribution of caffeine observed in this study. During storm events the dynamics of river plumes, including from the Columbia River (Fiedler and Laurs 1990), the largest source of freshwater flow to the eastern Pacific Ocean, may result in the transport of caffeine from river discharge to areas far away from river mouths. This could explain why the highest levels of caffeine were observed at two locations that do not have rivers discharging in the vicinity (Cape Lookout SP and Carl Washburne SP), while the caffeine concentration measured at the sampling locations near the Columbia River had caffeine levels below the reporting limit. Both of the locations with higher caffeine concentrations that were not near river mouths had salinities in the 23 PSU ranges, indicating that seawater was appreciably diluted relative to typical surface salinities in this region of the Pacific Ocean (32.5 PSU; Fiedler and Laurs 1990). 
An alternative explanation could be that areas outside of populated centers have wastewater treatment facilities or on-site systems that do not remove caffeine resulting in a greater caffeine burden; and that these sources are mobilized during storm events. This does not explain the level of caffeine in the Astoria/Warrenton area. Given the relatively high concentration of caffeine measured in the Columbia River (152 ng/L), it was surprising that the sample collected from the coastal ocean had caffeine levels below the reporting limit.

Caffeine concentrations in receiving water bodies can vary temporally due to seasonal changes in consumption, elimination efficiencies of WWTPs, and transport processes (Buerge et al. 2003; Benotti and Brownawell 2007). Benotti and Brownawell (2007) reported that caffeine concentrations in Jamaica Bay, New York were higher during dry weather conditions compared to wet weather conditions. Peeler et al. (2006) reported variable temporal differences in the levels of caffeine measured at the same locations over three sampling periods separated by several months.

The Oregon coast is a popular vacation destination during the summer months (July-September) and caffeine consumption could increase as a result of this transient 
population increase. Frequent wet weather during the months of November through March could also increase the caffeine burden to the coastal ocean if such conditions result in enhanced transport and reduced elimination efficiencies of caffeine in WWTPS. Therefore it would not be surprising to find temporal variations in caffeine concentrations along the Oregon Coast, which could include higher concentrations than reported in this study.

This study establishes the occurrence of caffeine in the coastal ocean off of the Oregon Coast. The results suggest that the occurrence of caffeine along the oregon Coast is associated with wet-weather conditions. The mechanisms by which storm events result in caffeine delivery to the coastal ocean were not addressed by this study. To gain a better understanding of the distribution of caffeine in the coastal ocean off of the Oregon coast, and potentially of other pollutants, the relative importance of different sources of caffeine, how these behave seasonally, and process that may affect the transport of caffeine once it enters the coastal ocean should be further researched. 


\section{CHAPTER 3: EXPRESSION OF HSP70, A MOLECULAR MARKER OF STRESS, IN THE GILL AND MANTLE TISSUE OF MYTILUS CALIFORNIANUS EXPOSED TO LOW CONCENTRATIONS OF CAFFEINE}

\section{INTRODUCTION}

Caffeine is recognized as a ubiquitous contaminant in aquatic ecosystems. Caffeine is among the most common organic contaminants of surface waters and has been detected in streams, lakes, estuaries and oceans (Buerge et al. 2003). The concentrations of caffeine typically reported from aquatic environments are in the low nanogram per liter range. It remains unclear whether such low concentrations of caffeine, 1/1000000th the concentration of a drip-brewed cup of coffee, have any measurable impact on aquatic organisms. Since caffeine is a drug with known physiological effects, even at low concentrations, and is constantly released to the aquatic environment via wastewater effluent and other anthropogenic activities, there is sufficient justification to explore the potential effects of environmentally relevant concentrations of caffeine on aquatic organisms.

The majority of the research on caffeine has been aimed at understanding its effects on humans, a fact that is not surprising given that caffeine is the world's most consumed non-prescription drug (Benowitz 1990). The modes 
of action of caffeine include: i) antagonizing adenosine receptors; ii) inhibiting phosphodiesterases; iii) sensitizing ryanodine-sensitive channels in the sarcoplasmic and endoplasmic reticulum to activation by calcium; and iv) antagonizing $\mathrm{GABA}_{\mathrm{A}}$ receptors at the benzodiazepine-positive modulatory site (Daly 2007).

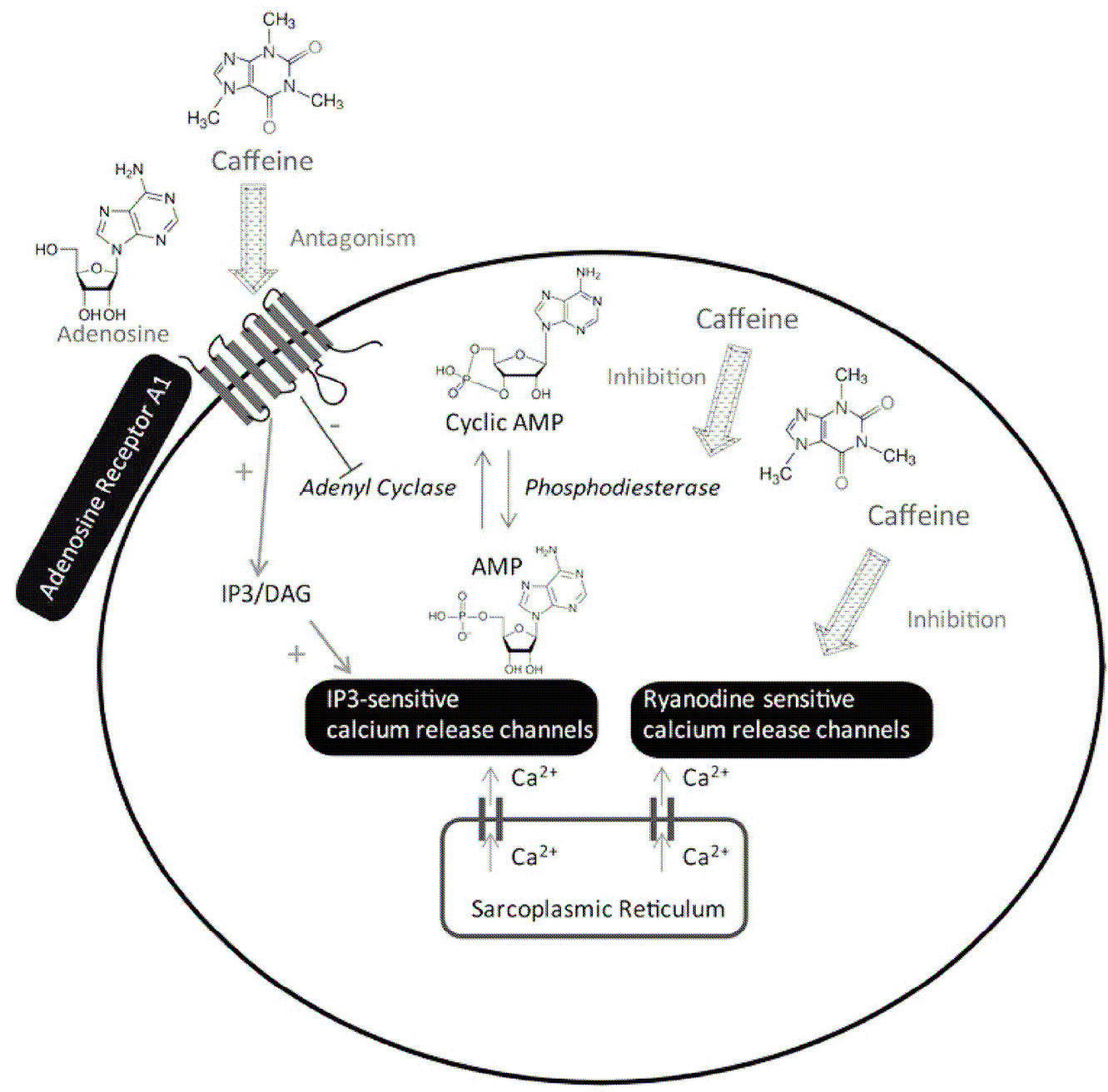

Figure 3.1: Cellular pathways and the specific points at which caffeine is known to act (from Rana et al. 2007). 
In humans, cytochrome P450 is involved in the metabolism of caffeine (Berthou et al. 1991). Although cytochrome P450 is highly conserved, caffeine is more toxic to other organisms, including horses, dogs, parrots, and spiders due to their underdeveloped capacity to metabolize the drug (Pollack et al. 2009).

Increasing concerns about the prevalence of caffeine in the aquatic environment have fueled a few studies investigating the effects of caffeine on aquatic organisms. Fraker and Smith (2004) found that ecologically relevant levels of some organic wastewater contaminants, including caffeine, had behavioral and physiological effects on northern leopard frog (Rana pipiens) tadpoles. Gagne et al. (2006) reported that, although caffeine was not very toxic to trout (Oncorhynchus mykiss) hepatocytes, it produced lipid peroxidation at a threshold concentration of $14 \mu \mathrm{M}$ after 48-hour exposure at $15{ }^{\circ} \mathrm{C}$. Moreover, in vitro incubation of caffeine with trout microsomes increased both the rate of oxidation of $\mathrm{NAPDH}$ and the lipid peroxidation in microsomes after a 60-minute incubation at $30^{\circ} \mathrm{C}$. The results of this study suggest that caffeine exposure could lead to oxidative damage at low milligram per liter concentrations. 
Other studies suggest that environmentally relevant levels of caffeine are not a threat to aquatic organisms. Smith and Burgett (2005) reported that environmentally relevant concentrations of caffeine $(0.6$ to $600 \mu \mathrm{g} / \mathrm{L}) \mathrm{did}$ not affect the survivorship or activity of the American toad (Bufo americanus) tadpoles. Similarly, Quinn et al. (2008) classified caffeine as non-toxic based on acute (mortality) and chronic (feeding behavior, attachment and growth) toxicity tests on the freshwater cnidarian Hydra attenuata.

Caffeine exposure impaired the reproduction of the water flea Ceriodaphnia dubia (IC50 = $44 \mathrm{mg} / \mathrm{L}$ ) and inhibited the growth of the fathead minnow Pimephelas promelas (IC50 = $71 \mathrm{mg} / \mathrm{L}$ ) (Moore et al. 2008). Given that these concentrations were several orders of magnitude higher than environmental concentrations, caffeine did not appear to pose a threat to freshwater organisms, but as the authors point out, there remains the potential for effects from long-term exposure.

There are few studies on the effect of caffeine on marine organisms, and none of these studies employed environmentally relevant levels of caffeine. Cheney et al. (1945) found that caffeine affects oxygen consumption and 
the normal rate of cleavage division in the fertilized eggs of the sea urchin, Arbacia puntulata. Nath and Rebhun (1976) reported inhibition of mitosis in sea urchin eggs exposed to caffeine. Caffeine was shown to induce bleaching in the tropical sea anemone Aiptasia pulchella, ostensibly through its effect on levels of intracellular protein phosphorylation (Sawyer and Muscataine 2001). Increased duration of exposure to caffeine resulted in a significant increase in the percent of symbiotic algae released from $A$. pulchella. A subsequent study on the effect of caffeine on four species of coral endosymbionts found that algal cultures grown in 60-mg/L caffeine exhibited up or down regulation of a number of proteins associated with glycolysis, photosynthesis, and the physiological stress response (Pollack et al. 2009). Heatshock proteins were upregulated 2 to 3 fold in the coral endosymbiont Symbiodinium sp. and down-regulated up to 9 fold in Symbiodinium goreaui.

Some challenges exist in detecting impacts to natural populations by contaminants that are found at low concentrations in the environment. Contaminants can cause changes at all levels of biological organization and subtle or chronic biological effects resulting in irreversible 
long-term changes could be occurring in apparently healthy ecosystems (Hyne and Maher 2004). These changes may not be initially detected if the focus of ecological risk assessment is on coarse levels of biological organization. HSPs have been suggested as sensitive biomarkers of the sub-lethal or subtle toxicity of pollutants (Sanders 1990; Depledge 1994; Lewis et al. 1999) because they are involved in protecting and defending cells from environmental offenses (Sanders et al. 1990) and their induction is much more responsive than traditional indices of contaminant effects (Feder and Hofmann 1999).

Several reviews of HSPs and their application in environmental monitoring are available (e.g. de Pomerai 1996; Pyza et al. 1997; Feder and Hofmann 1999; Lewis et al. 1999; Mukhopadhyay et al. 2003). Briefly, HSPs are proteins that are synthesized in response to cellular stress that induces denaturation of other proteins. Among the different families of HSPs, the 70-kDa family (Hsp70) is most highly conserved and has been most extensively studied. Four key features of Hsp70 have driven its application in environmental risk assessment: 1) it is highly conserved in a wide variety of organisms from bacteria to humans; 2) it responds to a variety of 
environmental stresses, including thermal stress, heavy metal exposure, organic pollutants, hypoxia/anoxia, salinity stress, and exposure to ultraviolet radiation; 3) its induction is very sensitive to environmental assaults; and, 4) its expression has been correlated to other toxicological end points.

Some concerns about the use of Hsp70 as a biomarker in environmental toxicology have been raised (Feder and Hofmann 1999; Staempfli et al. 2002). The stress history of an organism can affect the expression of HSPs and certain xenobiotic compounds have been reported to inhibit the expression of HSPs. The response of HSPS and induction thresholds may be specific to different tissues (Chapple et al. 1997; Feder and Hoffman 1999). Depending on the type and concentration of the tested pollutant, the timing of an induction of Hsp70 in response to pollutant stress can vary and can be missed by measuring over the wrong time periods (Staempfli et al. 2002).

Some of these concerns can be minimized in laboratory studies that assess the effect of a single contaminant and employ adequate controls for comparison. Collecting organisms from the same environment with adequate acclimation in the laboratory can help ensure that test 
organisms, including controls, have a similar stress history. Measuring the response of Hsp70 in different tissues and over several time periods can help to ensure that a tissue-specific or time-dependent induction is not missed. Finally, care must be observed when interpreting results of HSP bioassays and drawing conclusions about the toxicity of a contaminant. Despite the concerns raised about the use of Hsp70 as a biomarker in environmental toxicology, Hsp70 remains a potent and sensitive tool for investigating the toxicity of contaminants of concern (Mukhopadhyay et al., 2003)

The objective of this study was to investigate the toxicity of environmentally relevant concentrations of caffeine on the common intertidal mussel Mytilus californianus using Hsp70 as a biomarker of the effects of this ubiquitous aquatic contaminant. Mussels are ideal marine species to investigate the potential effects of contaminants because they are stationary, widespread, easy to collect, filter feeders that have been used widely in toxicity studies using Hsp70 as a biomarker of effect (Laporte 2005). M. californianus is one of the dominant species on the Oregon Coast. The study addressed the following questions: 
- Is Hsp70 expression in M. californianus increased by exposure to environmentally relevant concentrations of caffeine?

- Is there a difference in the expression of Hsp70 in different tissues of M. californianus exposed to caffeine?

- Does the expression of Hsp70 change with the duration of exposure to caffeine?

\section{METHODS}

Study Organisms and Acclimation Conditions

M. californianus mussels were collected at the Oregon Coast from a study site in the town of Yachats (N

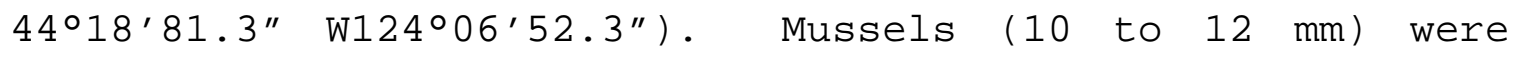
collected from the same area on a single day in september 2008 and transported in a chilled cooler to Portland state University. In the laboratory, mussels were acclimated in 10 gallon aquaria filled with UV filtered deionized water adjusted to a salinity of 32 PSU (Instant Ocean). The aquaria were connected to in-line chillers (Sealine) and to an in-tank filter system (Figure 3.2). The acclimation temperature was $10-11{ }^{\circ} \mathrm{C}$, similar to the temperature at the time of collection $\left(10-11{ }^{\circ} \mathrm{C}\right)$. After three days of acclimation the experiment was started. Mussels were held 
under a natural light cycle of approximately 12 hours of daylight and 12 hours of dark.

A pilot experiment verified that in-tank caffeine concentration did not decrease appreciably in seawater over a seven-day period. To test for caffeine degradation, a tank was set up with twelve mussels and spiked with a known concentration of caffeine. After one week, 1 liter samples of water were removed from the tank and caffeine degradation from initial concentration was verified using solid phase extraction (EnviCarb, Supelco) and GC-MS analysis.

Experimental design

M. californianus were exposed to one of four caffeine concentrations ranging from $0.05 \mu \mathrm{g} / \mathrm{L}$ to $0.5 \mu \mathrm{g} / \mathrm{L}$. These are realistic concentrations reported from different marine systems (Siegener and Chen 2002; Weigel et al. 2004; Peeler et al. 2006; Comeau et al 2008). Control mussels were not exposed to caffeine. Twelve randomly selected mussels were placed in each of the five caffeine treatments $(0,0.05$, $0.1,0.2$, or $0.5 \mu \mathrm{g} / \mathrm{L})$. The tank water was changed every five days and spiked with caffeine using a freshly prepared stock solution. After each water change, mussels were fed 5 ml of Instant Algae (Reed Mariculture). 
Four mussels from each treatment were sacrificed after 10, 20, and 30 days. Mussels were dissected and a sample of gill lamellae and mantle tissue from each mussel was stored in separate cryovials. Sample tissues were immediately frozen in liquid nitrogen and stored in a $-80{ }^{\circ} \mathrm{C}$ freezer until tissue preparation. No test organisms died during the experiment. Hsp70 concentrations in mussel tissues were subsequently measured using the protocol described by Buckley et al. (2001).

Tissue preparation

Approximately $100 \mathrm{mg}$ of tissue was ground in a small centrifuge tube using a pestle. The ground tissue was then homogenized in a 1:1 (volume/volume) solution of $2 \mathrm{X}$ homogenization buffer consisting of $32 \mathrm{mM}$ Tris-HCl (pH 6.8) and $2 \%$ sodium dodecyl sulfate (SDS). The homogenate was heated to $100^{\circ} \mathrm{C}$ for five minutes and then centrifuged at $12,000 \mathrm{~g}$ for 10 minutes. The supernatant was collected into a new centrifuge tube and the pellet discarded. The protein content of the supernatant was determined by the Bradford assay (Pierce, Rockford, IL, USA). The supernatant was stored in a $-80^{\circ} \mathrm{C}$ freezer until further analysis. Gill lamellae and mantle tissue were prepared using the same procedure. 


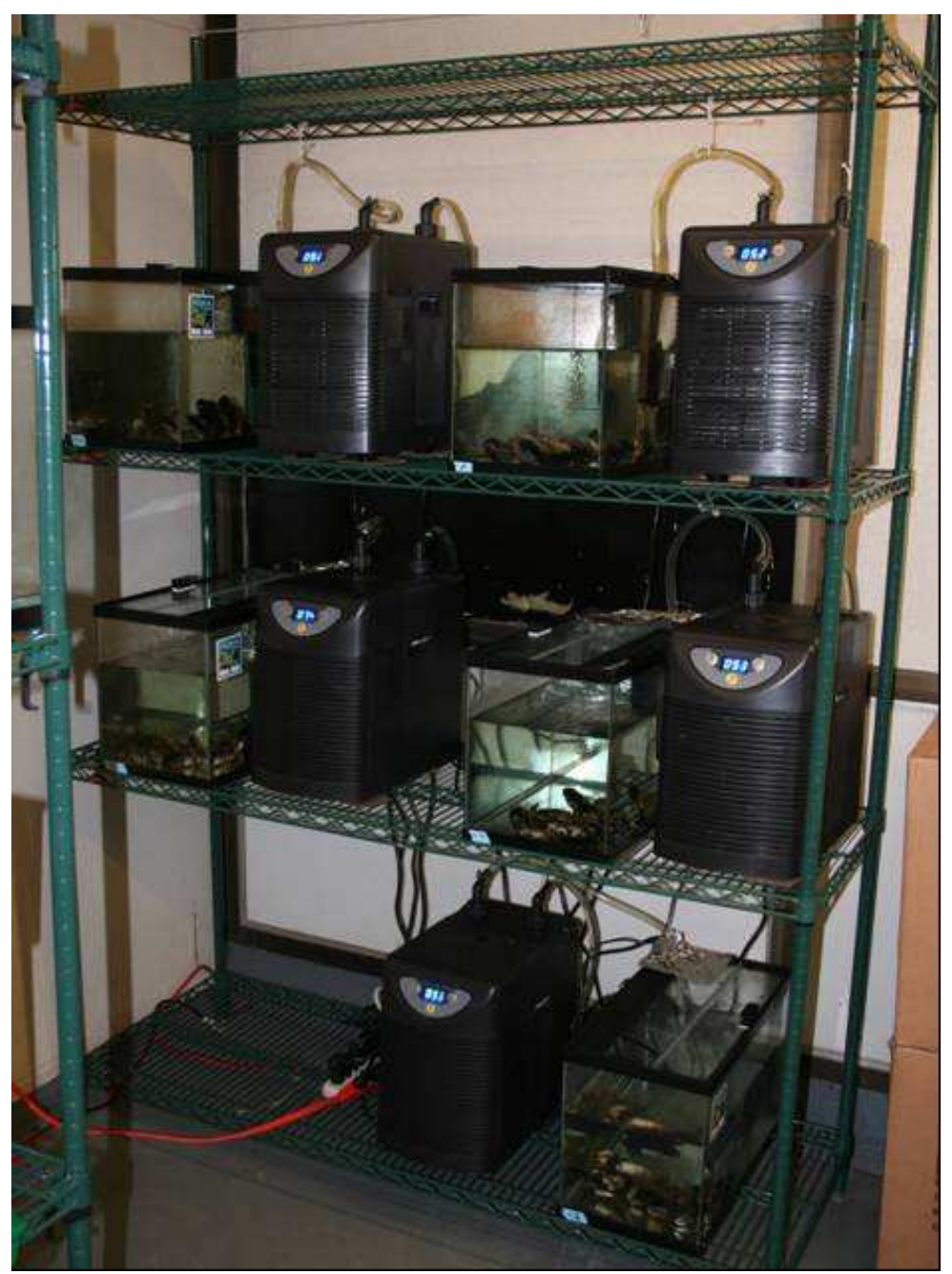

Figure 3.2: Experimental tanks. Tanks were connected to in-line chillers and the temperature maintained at $10^{\circ}-11 \mathrm{C}$.

\section{Electrophoresis and Immunochemical Assay of Hsp70}

Equal amounts of protein $(15 \mu \mathrm{g})$ from each sample were separated via SDS-polyacrylamide gel electrophoresis on 10 lane $10 \%$ polyacrylamide gels. One lane in each gel was loaded with Precision Plus Protein Kaleidoscope standard (Bio-Rad) and one with a standard sample used to calibrate protein expression within and among gels. The standard 
sample was from one of the experimental mussel samples. Following approximately 1.5 hours of electrophoresis at 150 $\mathrm{V}$, the proteins were transferred to nitrocellulose blots using wet electrophoretic transfer at $30 \mathrm{~V}$ overnight (approximately 15 hours).

Nitrocellulose blots were blocked in 5\% non-fat dry milk in $1 X$ PBS for one hour. The immunodetection was performed using an Hsp70 polyclonal antibody (Hsp70 (K-20)R, Santa Cruz Biotechnology) that reacts only with the Hsp70 isoform. Blots were then incubated for 1.5 hours in the primary antibody diluted 1:5000 in 5\% non-fat dry milk in 1X PBS, followed by three ten minute washes in $1 X$ PBS with $0.1 \%$ Tween-20. Blots were then incubated for 1 hour in peroxidase-conjugated goat-anti-rabbit antibody (Thermo Scientific) diluted $1: 5000$ in 5\% non-fat dry milk in $1 x$ PBS, followed by six five minute washes in $1 X$ PBS with $0.1 \%$ Tween-20. Blocking and incubation in primary and secondary antibody was done under constant agitation at room temperature.

Western blots were developed using Supersignal West Pico Chemiluminescent Substrate (Thermo Scientific) and exposed to film (Kodak BioMax MR-1). Scanning densitometry, using ImageJ (http://rsb.info.nih.gov/ij/), was used to 
determine the levels of Hsp70 expression relative to the standard sample.

Data Analysis

Differences in Hsp70 expression were analyzed with a twoway ANOVA with caffeine concentration and exposure duration as the fixed factors and Hsp70 concentration as the dependent variable. Significant fixed factors were further investigated using a one-way ANOVA and post-hoc Tukey tests. Statistical analyses were performed using SPSS 17.0 $(2008)$

During the first ten days of the experiment the chiller for the caffeine treatment of $0.1 \mu \mathrm{g} / \mathrm{L}$ experienced a power outage. When the power outage was discovered, the temperature in that tank was $23{ }^{\circ} \mathrm{C}$ and could have been at that temperature for a maximum of 48 hours. Although, mussel samples from that treatment were collected and analyzed for Hsp70 expression, the data are not included since this represented a thermal change that likely affected Hsp70 expression.

\section{RESULTS}

The primary antibody used against Hsp70 was highly specific producing bands only at approximately $70 \mathrm{kDa}$. The 
gill lamellae and mantle tissue of control mussels exhibited basal levels of Hsp70 that were similar for the duration of the experiment and had low variability. This could be due to the thermal history of the mussels, which were collected from the high intertidal area where thermal stress is a common occurrence. Sample Western blots for the gill lamellae and mantle tissue are presented in Figure 3.3, A and B, respectively.

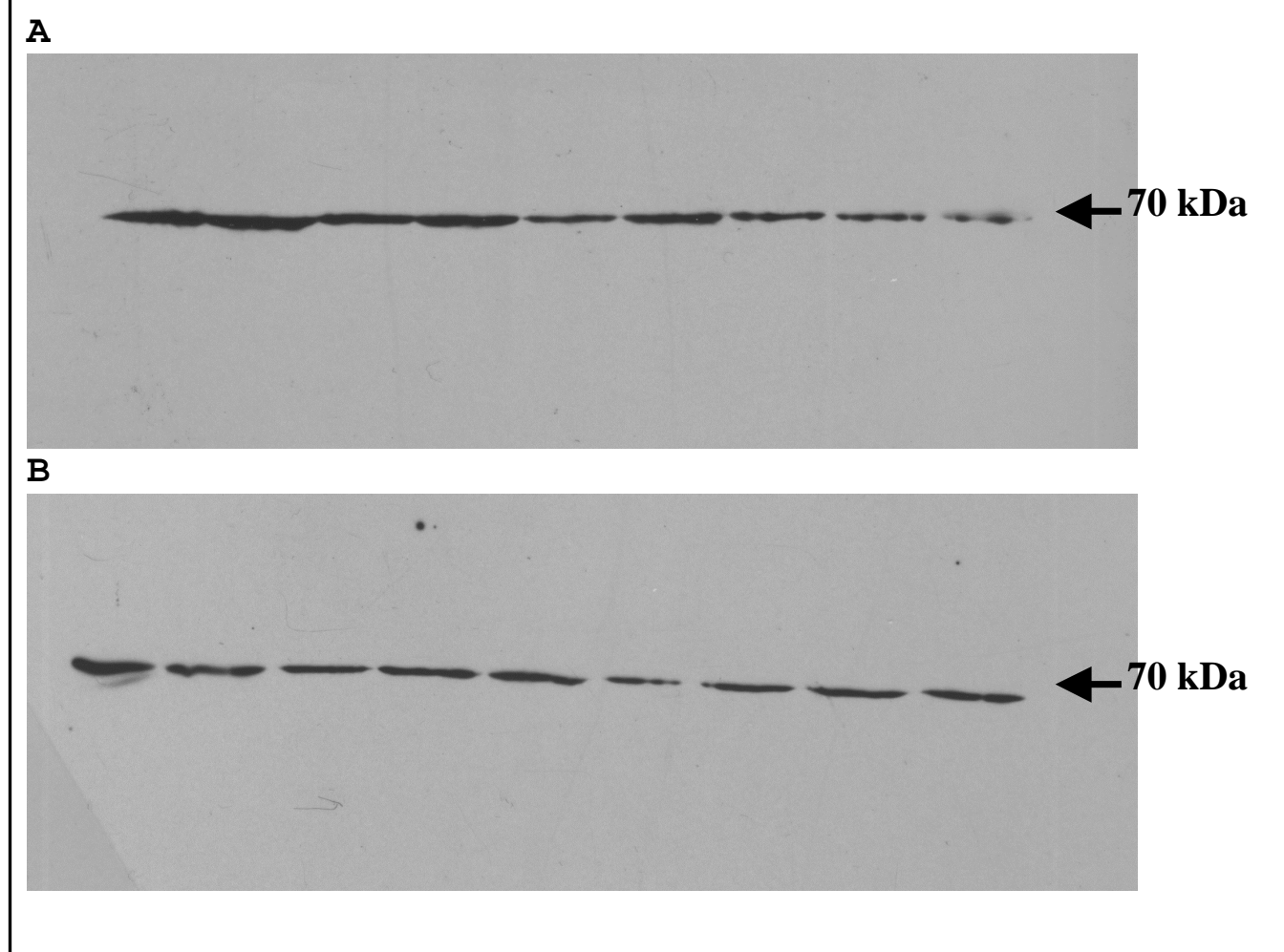

Figure 3.3: Sample Western blots from selected (A) gill and (B) mantle tissue samples. (Note: Since tissue samples were randomly loaded on the 10-lane gel, the sample blots shown in this figure do not illustrate trends in Hsp70 expression) 
Hsp70 expression in the gill tissue responded to caffeine exposure. The response was time dependent, but did not exhibit a linear dose-response relationship with increasing concentration, although interaction between dose and time was significant (Figure 3.4; Table 3.1).

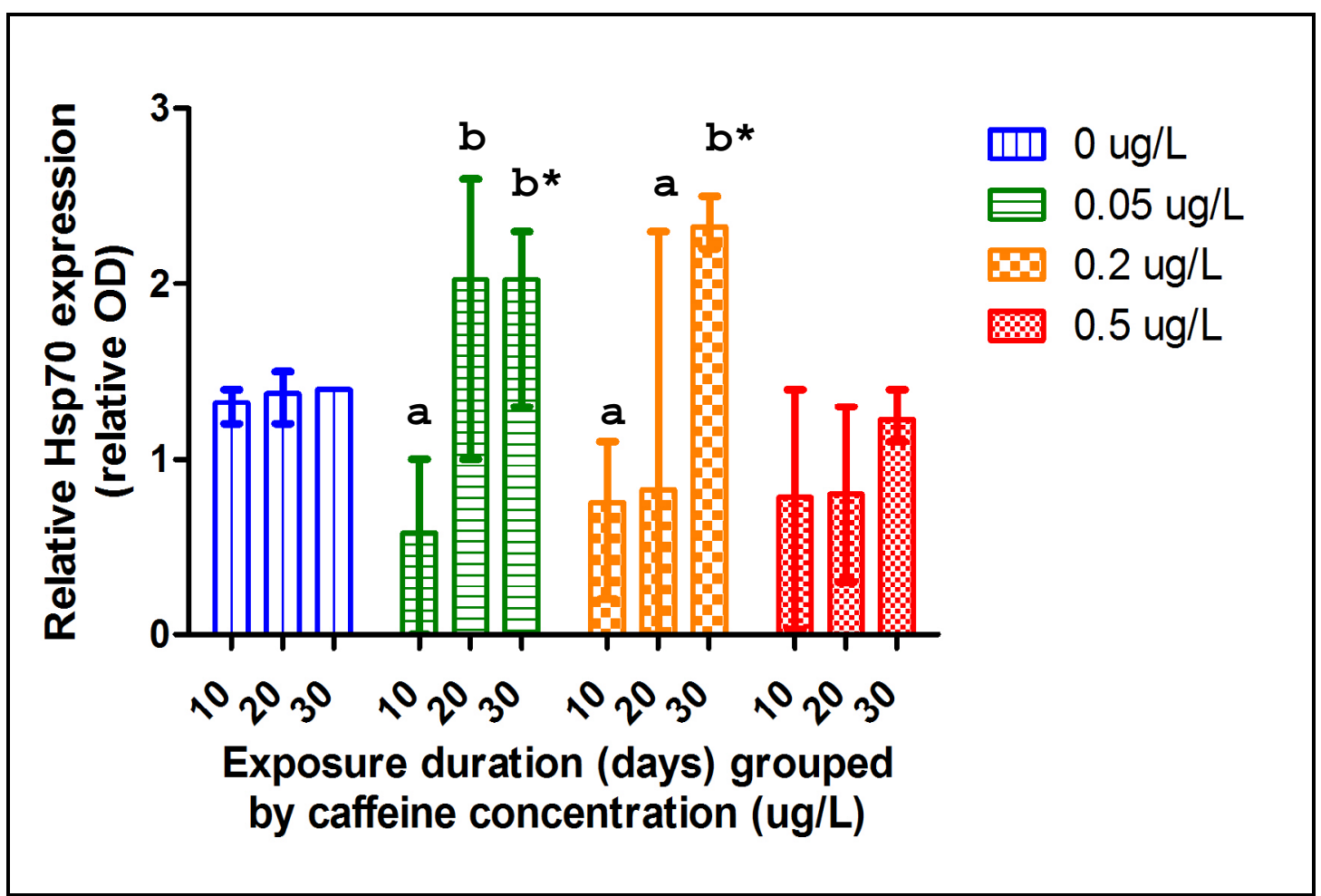

Figure 3.4: Mean Hsp70 expression in the gill lamellae of $M$. californianus exposed to three concentrations of caffeine for 10 , 20, and 30 days. Error bars represent the range of Hsp70 concentrations $(\mathrm{n}=4)$. Significant differences in Hsp70 concentration for exposure duration within caffeine dose are indicated by the letter convention (p-value <0.05). An asterisk indicates that the Hsp70 expression for that exposure duration was significantly different from the control (p-value <0.05).

Table 3.1: Summary of two-way ANOVA results for the gill tissue.

\begin{tabular}{|l|r|r|r|r|}
\hline Source & Sum of Squares & df & \multicolumn{1}{|c|}{$\mathbf{F}$} & p-value \\
\hline Dose & 2.336 & 3 & 3.104 & 0.039 \\
\hline Time & 6.296 & 2 & 12.548 & 0.000 \\
\hline Dose * Time & 6.140 & 6 & 4.079 & 0.003 \\
\hline
\end{tabular}


A profile plot of mean Hsp70 expression of the three caffeine treatments and the control over time is presented in Figure 3.5. This representation of Hsp70 expression is meant to illustrate overall trends. Some of the trends are not significant due to high variability in Hsp70 concentrations within treatment.

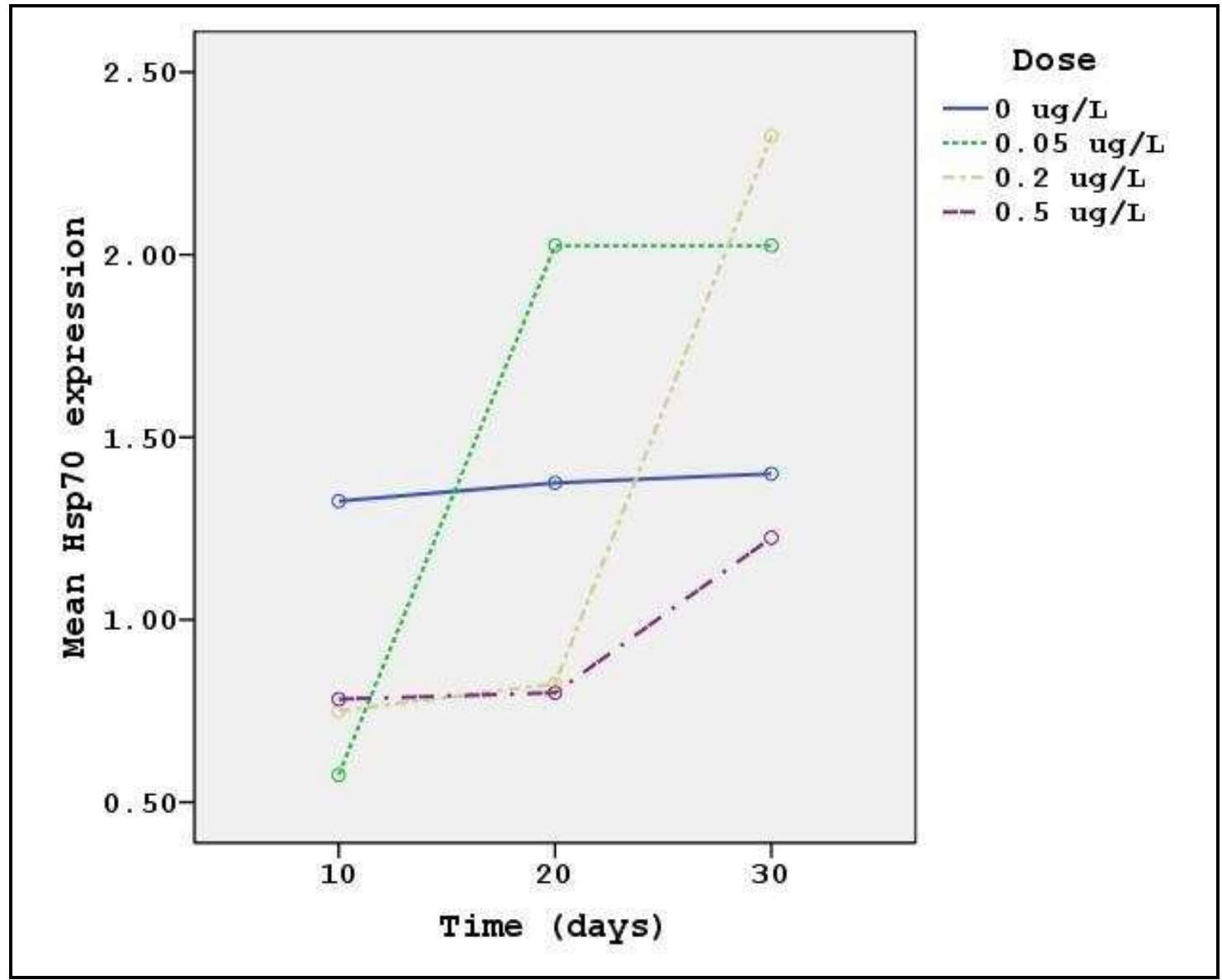

Figure 3.5: Profile plot of mean Hsp70 expression over the duration of the experiment. The profile plot illustrates overall trends, but some trends were not significant due to high variability in Hsp70 expression within treatment. 
Caffeine initially produced an inhibitory effect on Hsp70 followed by a time and dose dependent recovery. After thirty days, Hsp70 in the mussels exposed to 0.05 and 0.2 $\mu \mathrm{g} / \mathrm{L}$ caffeine was moderately up regulated relative to controls. At 10 days of exposure to caffeine, mean Hsp70 levels of mussels in all three caffeine treatments were lower than in the control mussels. This trend was not statistically significant because individual mussels exhibited marked variability in the response of Hsp70, but some of the mussels in each of the three treatments had very low or no detectable Hsp70. Similar variability in Hsp70 was not exhibited by the control mussels during the time course of the experiment.

Exposure to caffeine at $0.05 \mu \mathrm{g} / \mathrm{L}$ induced a moderate up-regulation of Hsp70 in the gill lamellae of $M$. californianus after 20 days of exposure. Hsp70 levels remained elevated after 30 days of exposure. In the 0.2 $\mu \mathrm{g} / \mathrm{L}$ treatment, the levels of Hsp70 did not exhibit a upregulation until 30 days of exposure. The maximum Hsp70 levels detected were similar for the 0.05 and $0.2 \mu \mathrm{g} / \mathrm{l}$ treatments. Interestingly, in the highest caffeine treatment $(0.5 \mu \mathrm{g} / \mathrm{L})$, a similar increase in Hsp70 
expression was not observed during the duration of this experiment.

M. californianus exposed to caffeine exhibited a different pattern of Hsp70 expression in the gill lamellae and the mantle tissue. After 30 days, Hsp70 expression in the mantle tissue (Figure 3.6) was unresponsive to caffeine exposure. Results of the two-way ANOVA are summarized in Table 3.2.

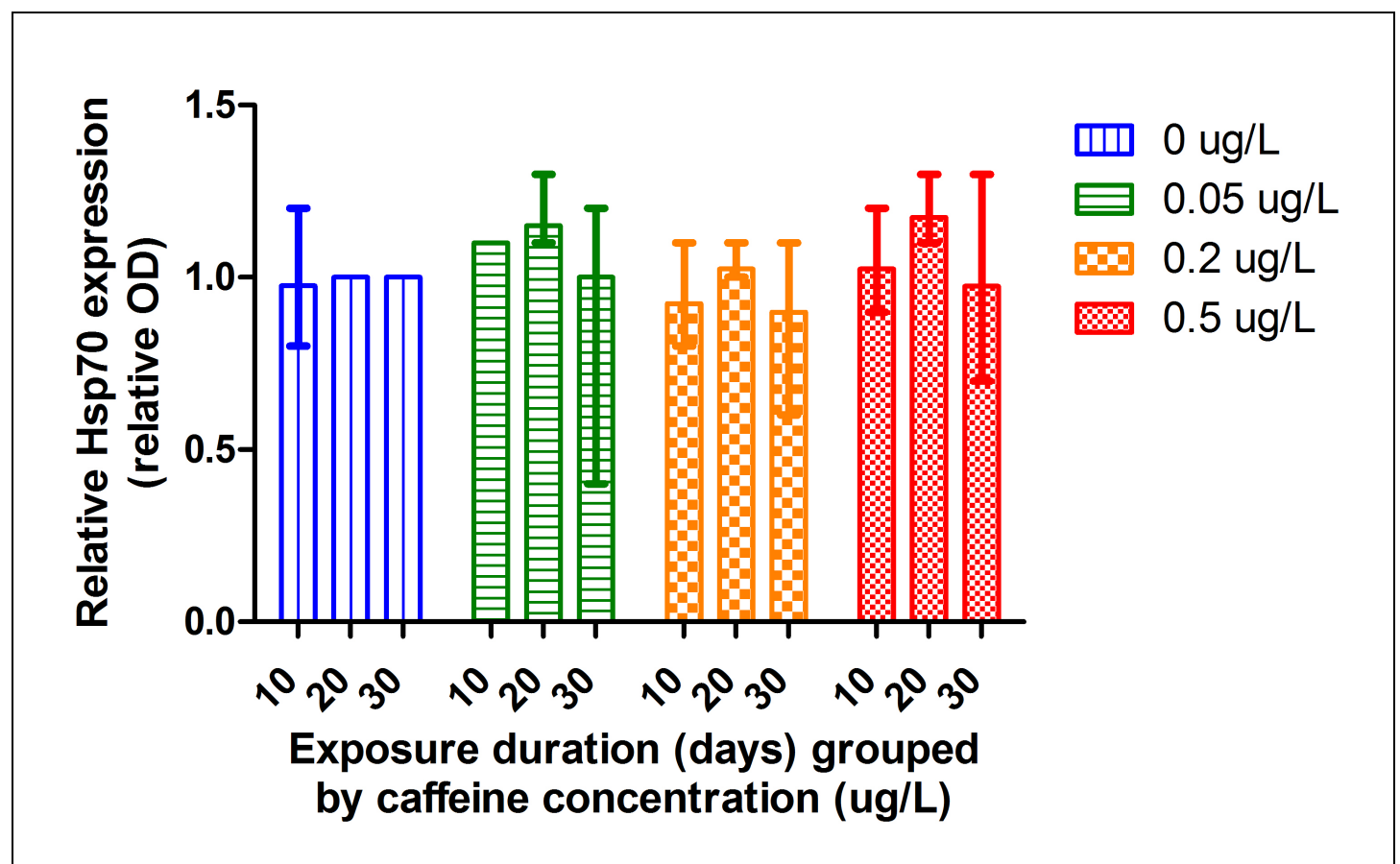

Figure 3.6: Relative Hsp70 expression in the mantle tissue of $M$. californianus exposed to three concentrations of caffeine for 10 , 20, and 30 days. Error bars represent the range of Hsp70 concentrations $(n=4)$. 
Table 3.2: Summary of the two-way ANOVA results for the mantle tissue.

\begin{tabular}{|l|r|r|r|r|}
\hline Source & Sum of Squares & df & F & p-value \\
\hline Dose & 0.181 & 3 & 2.308 & 0.930 \\
\hline Time & 0.121 & 2 & 2.323 & 0.112 \\
\hline Dose * Time & 0.056 & 6 & 0.356 & 0.902 \\
\hline
\end{tabular}

\section{DISCUSSION}

Caffeine, a potent neuroactive drug, is recognized as a ubiquitous contaminant in aquatic systems. Traditional ecotoxicology endpoints suggest that the levels of caffeine currently detected in aquatic systems do not pose a threat to aquatic organisms. There remains a potential for sublethal effects not detected by traditional endpoints and effects from long-term exposure to low levels of caffeine.

This study investigated the effect of caffeine on the intertidal mussel M. californianus using Hsp70 as a biomarker of cellular stress in response to exposure to environmentally relevant concentrations of caffeine. Since Hsp70 affords cellular protection from environmental assaults, it has been employed as a biomarker of sublethal effects not detected by traditional endpoints.

This study demonstrates that Hsp70 in the gill tissue of M. californianus responds to exposure at environmentally 
relevant concentrations of caffeine. The response of Hsp70 in the gill tissue exhibited a complex pattern across dose and time. Initially, caffeine appears to have an attenuating effect on Hsp70 expression for all caffeine levels tested. This trend, however, was not significant, likely due to the small sample size and high variability of measured Hsp70 concentrations. High variability in Hsp70 expression in response to contaminant exposure can mask trends and has been reported in other studies (Staempfli et al. 2002; Laporte 2005).

Increasing the duration of exposure resulted in upregulations of Hsp70, which was dependent on caffeine concentration. Hsp70 was up regulated after 20 days in the $0.05 \mu \mathrm{g} / \mathrm{L}$ caffeine treatment and after 30 days in the 0.2 $\mu \mathrm{g} / \mathrm{L}$ treatment, but did not exhibit a similar increase in the $0.5 \mu \mathrm{g} / \mathrm{L}$ treatment over the 30-day duration of this experiment. The mechanism inducing this type of Hsp70 response to caffeine exposure remains to be elucidated.

Only one previous study has investigated the response of Hsp70 to caffeine exposure in aquatic organisms. Pollack et al. (2009) assessed the effect of caffeine on coral algal endosymbionts by identifying proteins sensitive to caffeine exposure. Heatshock proteins were up-regulated 2 
to 3 fold in the coral endosymbiont symbiodinium sp. and down-regulated up to 9 fold in Symbiodinium goreaui.

The concentration of caffeine used to incubate coral algal endosymbionts in the study by Pollack et al. (2009) falls within the range that would be toxic if found in human blood serum. It is not surprising that an effect on HSP proteins was observed at this high concentration of caffeine since it can potentially inhibit many cellular processes. All known stresses, if sufficiently intense, induce HSP expression (Feder and Hoffman 1999).

In contrast, the concentrations of caffeine used in the present study were in the ng/L to $\mu \mathrm{g} / \mathrm{L}$ level. Due to the large diversity of Hsp70 inducers, the cellular stress response is thought to be triggered by different mechanisms of toxicity, among which protein damage (e.g. misfolding) would be the common link (Ait-Aissa et al. 2000). There is currently no evidence that the low levels of caffeine tested in this experiment are proteotoxic.

Prolonged oxidative stress from chronic exposure to caffeine could result in an upward regulation of Hsp70 as the organism attempts to cope with cellular damage. Gagne et al. (2006) reported that exposure to caffeine could lead to oxidative damage of trout hepatocytes. However, the 
concentrations of caffeine at which trout hepatocytes were incubated were in the $\mathrm{mg} / \mathrm{L}$ range, 1000 times higher than the concentrations tested in this study. The role of oxidative stress in inducing an Hsp70 response in the gill of M. californianus exposed to low levels of caffeine could be investigated further by verifying that oxidative stress is occurring (e.g. quantifying lipid peroxidation) .

Other mechanisms not related to proteotoxicity may also induce an Hsp70 response. In humans, caffeine is able to significantly block adenosine receptors at low serum concentrations ( $\mu$ mol) and this is considered the most common mode of action of caffeine (Fredholm et al. 1999). Blocking of adenosine receptors by caffeine results in a loss of the inhibitory effect of adenosine and triggers a catecholaminergic response. Catecholamines have previously been shown to up-regulate intracellular and extracellular Hsp72 in laboratory rats (Johnson et al. 2005).

Several studies have identified neuroendocrine and nervous system functions in molluscs that are analogous to the hypothalamic-pituitary system of vertebrates; similar elements are at the basis of the response and triggering (Stefano et al. 2002; Fabbri et al. 2008). For example, adenosine receptors have been reported from the mussel 
Mytilus edulis. Theophylline, which bears structural and pharmacological similarity to caffeine, blocked the inhibitory effects of a potent adenosine analog on neurotransmitter release in in vitro preparations from the pedal ganglia of $M$. edulis (Barraco and Stefano 1990) In the oyster Crassostrea gigas, circulating noradrenaline and dopamine have been shown to increase in response to physiological stress (Lacoste et al. 2001a).

Assuming that the mode of action of caffeine on adenosine receptors is similar between vertebrates and molluscs, exposure to low levels of caffeine could stimulate the release of catecholamines resulting in induction of Hsp70 in M. californianus. In at least one study, noradrenaline was shown to induce the Hsp70 gene promoter in the oyster Crassostrea gigas and abalone Haliotis tuberculata (Lacoste et al. 2001b). The authors postulated that the integrated response to stress is related to the heat shock response.

Cell signal transducers, such as changes in intracellular $\mathrm{pH}$ cyclic AMP, $\mathrm{Ca} 2+, \mathrm{Na}+$ inositol trisphosphate, protein kinase $\mathrm{C}$, and protein phosphatases, have also been implicated in the modulation of Hsp70 expression (Kiang and Tsokos 1998). For example, a study of 
U-937 human promonocytic cells showed that treatment with the CAMP increasing agent isoproterenol plus theophylline decreased basal levels of Hsp70 (Vilaboa et al. 1995). Caffeine can affect many of these cell signal transducers (see Figure 3.1). Caffeine's effect on cell signal transducers could potentially mediate an Hsp70 response.

While the potential mechanisms detailed above could explain the observed up-regulation of Hsp70 in the gill lamellae of $M$. californianus with caffeine exposure, they do not explain the transient and concentration-dependent attenuation of Hsp70 observed here. A quenching phenomenon of Hsp70 has been described in some organisms exposed to some types of contaminants. Arts et al. (2004) proposed that the ability to inhibit HSP induction might indicate a more toxic response than producing elevated levels of these proteins, which indicates that the organism is able to maintain homeostasis under environmental assault.

In discussing this phenomenon, Eckwert et al. (1997) proposed that the dose-response curve for Hsp70 could be divided into three sections: (1) homeostasis: a state of basal Hsp70 expression, (2) compensation: a state of stress accompanied by Hsp70 induction, and (3) non-compensation: a state of severe stress and pathological damage blocking 
Hsp70 expression. This type of response was observed in the rotifer Brachionus plicatillis. Hsp60 levels of $B$. plicatillis exposed to crude oil in the laboratory were only higher than control rotifers at very low concentrations of crude oil (Wheelock et al. 1999). The model proposed by Eckwert et al. (1997) does not account for the duration of the stress, but the duration of stress can interact with dose to alter the response of Hsp70.

Such a quenching phenomenon could explain the time and concentration-dependent attenuation of Hsp70 observed in this study. In the case of the gill lamellae of $M$. californianus, the attenuation of Hsp70 was transient and concentration dependent. Gill tissue from mussels exposed to the lowest caffeine concentration exhibited a faster recovery to levels equal to the control mussels. The gill tissue from all but the highest treatment eventually exhibited a moderate time-dependent up-regulation of Hsp70, relative to controls. The actual mechanism(s) involved in quenching (or attenuating) the HSP response has been poorly investigated, but has been hypothesized to be the result of tissue damage (Ekwert et al. 1997). This is not likely to be the case with caffeine since the attenuation of Hsp70 in the gill lamellae was transient. 
Unlike the gill lamellae, the mantle tissue of $M$. californianus did not exhibit an Hsp70 response over the duration of this experiment. Although HSP expression is a ubiquitous molecular mechanism for coping with stress, the HSP response to stresses can be tissue specific (Feder and Hofmann 1999). Chapple et al. (1997) found tissue-specific inducibility of Hsp70 in $M$. edulis despite all tissues being exposed to the same temperatures. Compared with mantle and adductor muscle tissues, gill tissue showed the greatest increase in levels of Hsp70 proteins. Other tissues of $M$. californianus may exhibit an Hsp70 response to caffeine exposure, but this remains to be tested.

Caffeine is a potent neuroactive drug that is recognized as a ubiquitous contaminant in aquatic systems. M. californianus exposed in the laboratory to environmentally relevant concentrations of caffeine exhibited an Hsp70 response. Since Hsp70 affords cellular protection from environmental assaults, both the upregulation after prolonged exposure and the potential attenuation of the response should be investigated further. 


\section{CHAPTER 4: CONCLUSIONS}

This study confirms the presence of caffeine in the coastal ocean off of the Oregon Coast and provides laboratory evidence that environmentally relevant concentrations of caffeine can exert an effect on $M$. californianus gill tissue at the molecular level.

The results from this study suggest that along the Oregon Coast caffeine loading is associated with wetweather events. The introduction of caffeine into the coastal ocean likely occurs as pulses associated with rainfall events that overwhelm WWTPs and/or mobilizes other sources of caffeine (e.g. septic tank leachate and storm water run off). A lack of agreement between caffeine concentrations and the presence of potential sources of caffeine pollution suggests that along the Oregon Coast the transport of contaminants, such as caffeine, from source watersheds to more distant areas may be significant; or that the significance of the contribution of caffeine from sources other than WWTPS may be underestimated. Either way, this study illustrates the importance of understanding the behavior of contaminant pathways and transport mechanisms.

M. californianus exposed in the laboratory to environmentally relevant concentrations of caffeine 
exhibited an Hsp70 response. The duration of this experiment was limited to 30 days and it remains unclear how Hsp70 in the gill tissue or other tissues may respond under sustained chronic exposure to low concentrations of caffeine. It cannot be ruled out that caffeine may exacerbate the effects of stress from other environmental stresses including other contaminants.

Since Hsp70 affords cellular protection from environmental assaults, both the up-regulation after prolonged exposure and the potential attenuation of the response should be investigated further. 


\section{LITERATURE CITED}

Ait-Aissa, S., Porcher, J.M., Arrigo, A. P., and Lambre, C. (2000). Activation of the hsp70 promoter by environmental inorganic and organic chemicals: relationship with cytotoxicity and lipophilicity. Toxicology 145:147157.Barone, J. J. and Roberts, H. R. (1996). Caffeine Consumption. Food and Chemical Toxicology 34:119-129.

Arts, M. J., Schill, R. O., Knigge, T., Eckwert, H., Kammenga, J. E., and Kohler, H. R. (2004). Stress Proteins (hsp70, hsp60) Induced in Isopods and Nematodes by Field Exposure to Metals in a Gradient near Avonmouth, UK. Ecotoxicology 13:739-755.

Barraco, R. A. and Stefano, G. B. (1990). Pharmacological Evidence for the Modulation of Monoamine Release by Adenosine in the Invertebrate Nervous System. Journal of Neurochemistry 54:2002-2006.

Benedict, R. T. and Neumann, C. M. (2004). Evaluating Oregon's Beach Sites for Application to United States Environmental Agency's BEACH Act Criteria. Marine Pollution Bulletin 49:630-636.

Benotti, M. J. and Brownawell, B. J. (2007). Distributions of Pharmaceuticals in an Urban Estuary during both Dry and Wet-Weather Conditions. Environmental Science and Technology 41:5795-5802.

Benowitz, N. L. (1990). Clinical Pharmacology of Caffeine. Annual Review of Medicine 41:277-288.

Berthou, F., Flinois, J. P., Ratanasavanh, D., Beaune, P., Riche, C., and Guillouzo, A. (1991). Evidence for the involvement of several cytochromes $\mathrm{P}-450$ in the first steps of caffeine metabolism by human liver microsomes. Drug Metabolism and Disposition 19:561-567.

Bradley, P. M., Barber, L. B., Kolpin, D. W., McMahon, P. B., and Chapelle, F. H. (2007). Biotransformation of Caffeine, Cotenine, and Nicotine, in Stream Sediments: Implications for Use as Wastewater Indicators. Environmental Toxicology and Chemistry 26:116-1121.

Buckley, B.A., M.-E. Owen, G.E. Hofmann (2001). Adjusting the thermostat: the threshold induction temperature for the heat-shock response in intertidal mussels (genus Mytilus) changes as a function of thermal history. J. Exp. Biol. 204, 3571-3579

Buerge, I. J., Poiger, T. Muller, M. D., Buser, H. R. (2003). Caffeine, an Anthropogenic Marker for Wastewater Contamination of Surface Waters. Environmental Science and Technology 691-700. 
Carballa, M., Omil, F., Lema, J.M., Llompart, M., GarciaJares, I. Rodriguez, C. Gomez, M., and Ternes, T. (2004). Behavior of pharmaceuticals, cosmetics and hormones in a sewage treatment plant. Water Resources 38:2918-2926.

Chapple, J. P., Smerdon, G. R., and Hawkins, J. S. (1997). Stress-70 Protein Induction in Mytilus edulis: TissueSpecific Responses to Elevated Temperature Reflect Relative Vulnerability and Physiological Function. Journal of Experimental Marine Biology 217:225-235.

Cheney, R.H. (1945). The Effects of Caffeine on Oxygen Consumption and Cell Division in the Fertilized Egg of the Sea Urchin, Arbacia punctulata 29:63-72.

Comeau, F., Surette, C., Brun, G. L., and Losier, R. (2008). The Occurrence of Acidic Drugs and Caffeine in Sewage Effluents and Receiving Waters from Three Coastal Watersheds in Atlantic Canada. Science of the Total Environment 396:132-146.

Daly, J.W. (2007). Caffeine Analogs: Bioledical Impacts. Cell and Molecular Life Sciences 64:2153-2169.

Depledge, M. H. (1994). The Rational Basis for the Use of Biomarkers as Ecotoxicological Tools. In M.C. Fossi and C. Leonzio (eds.) Nondestructtive Biomarkers in Vertebrates, pp. 261-285. Boca Raton, Florida: Lewis Publishers.

De Pomerai, D. I. (1996). Heat-shock Proteins as Biomarkers of Pollution. Human and Experimental Toxicology 15:279285 .

Dorfman, M. and Sinclair Rosselot, K. (2009). Testing the Waters: A Guide to Water Quality at Vacation Beaches. Natural Resources Defense Council Open-File Report. . Natural Resources Defense Council, New York pp OR1-OR6. Eckwert, H., Alberti, G., and Koehler, H.R. (1997). The Induction of Stress Proteins (hsp) in Oniscus asellus (Isopoda) as a molecular marker of multiple heavy metal exposure: I. Principles and Toxicological Assessment. Ecotoxicology 6:249-262.

Fabbri, E., Valbonesi, P., and Franzellitti, S. (2008). HSP Expression in Bivalves. Invertebrate Survival Journal $5: 135-161$.

Feder, M. E. and Hofmann, G. E. (1999). Heat-Shock Proteins, Molecular Chaperones, and the Stress Response: Evolutionary and Ecological Physiology. Annual Review of Physiology 61:243-282.

Ferreira, A. P. (2005). Anthropogenic Pollution in Aquatic Environment: Development of Caffeine as an Indicator. International Journal of Environmental Health Research $15: 303-311$. 
Fiedler, P. and Laurs, M. (1990). Variability of the Columbia River Plume Observed in Visible and Infrared Satellite Imagery. International Journal of Remote Sensing $11: 999-1010$.

Fraker, S. L. and Smith, G. R. (2004). Direct and interactive effects of ecologically relevant concentrations of organic wastewater contaminants on Rana pipiens tadpoles. Environmental Toxicology 19:250-256.

Fredholm, B.B., Battig, K., Holmen, J., Nehlig, A., and Zvarrtau, E. E. (1999). Actions of Caffeine in the Brain with Reference Factors that Contribute to Its Widespread Use. Pharmacological Reviews 51:83-133.

Gagne, F. and Blaise, C. (2006). Occurrence of Pharmaceutical Products in a Municipal Effluent and Toxicity to Rainbow Trout (Oncorhyncus mykiss) hepatocytes. Ecotoxicology and Environmental safety $64: 329-336$.

Gardinali, P. R. and Zhao, X. (2002). Trace Determination of Caffeine in Surface Water Samples by Liquid Chromatography-Atmospheric Pressure Chemical IonizationMass Spectrometry (LC-APCI-MS). Environment International $28: 521-528$.

Grant, S. B., Kim, J. H., Jones, B. H., Jenkins, S. A., Wasyl, J., and Cudabacks, C. (2005). Surf Zone Entrainment, Along-Shore Transport, and Human Health Implications of Pollution from Tidal Outlets. Journal of Geophysical Research 110:C10025.

Hinkle, S.R., Weick, R.J., Johnson, J.M., Cahill, J.D., Smith, S.G., and Rich, B.J. (2005). Organic Wastewater Compounds, Pharmaceuticals, and Coliphage in Ground Water Receiving Discharge from Onsite Wastewater Treatment Systems near La Pine, Oregon: Occurrence and Implications for Transport. USGS Open-File Report; U.S. Government Printing Office: Washington, DC.

Hyne, R.V. and Maher, W.A. (2003). Invertebrate biomarkers: links to toxicosis that predict population decline. Ecotoxicology and Environmental Safety 54:366-374. Imre, S., Oztunc, A., Celik, T., and Wagner, H. (1987). Isolation of Caffeine from the Gorgonian Paramuricea chamaeleon. Journal of Natural Products 50:1187.

Johnson, J.D., Campisi, J., Sharkey, C. M., Kennedy, S. L., Nickerson, M., and Fleshner, M. (2005). Adrenergic receptors mediate stress-induced elevations in extracellular Hsp72. Journal of Applied Physiology $99: 1789-1795$. 
Jingyu, S., Kanghou, L. and Zhigang, J. (1984). Studies on the Chemical Constituents of the Chinese Gorgonian-A New Marine C29-Sterol from Echinogogia pseudossapo. Acta Scientiarum Naturalium Universitatis Sunyatseni.

Knee, K. L., Gossett, R., Boehm, A. B., and Paytan, A. (2010). Caffeine and Agricultural Pesticide Concentrations in Surface Water and Groundwater on the North Shore of Kauai (Hawaii, USA). Marine Pollution Bulletin (In Press). Kiang, J. G. and Tsokos, G. C. (1998). Heat Shock Protein 70 kDa: Molecular Biology, Biochemistry, and Physiology. Pharmacology and Therapeutics 80:183-201.

Lacoste, A., De Cian, M. C., Cueff, A., and Poulet, S. A. (2001). Noradrenaline and a-adrenergic signaling induce the hsp70 gene promoter in mollusc immune cells. Journal of Cell Science 114:3557-3564.

Lacoste, A., Malham, S. K., M. C., Cueff, A., and Poulet, S. A. (2001). Stress-Induced Catecholamine Changes in the Hemolymph of the Oyster Crassostrea gigas. General and Comparative Endocrinology 122:181-188.

Laporte, P.F. (2005). Mytilus trossulus hsp70 as a biomarker for arsenic exposure in the marine environment: Laboratory and real-world results. Biomarkers 10:417-428.

Lewis, R., Handy, R. D., Cordi, Z., Billinghurst, Z., and Depledge, M. H. (1999). Stress proteins (HSP's) : Methods of Detection and Their Use as an Environmental Biomarker. Ecotoxicology $8: 351-368$.

Lin, A. Y. C., Yu, T. H., and Lateef, S. K. (2009). Removal of pharmaceuticals in secondary wastewater treatment processes in Taiwan. Journal of Hazardous Materials $167: 1163-1169$.

Matamoros, V., Arias, C., Brix, H., and Bayona, J. M. (2009). Preliminary Screening of Small-Scale Domestic Wastewater Treatment Systems for Removal of Pharmaceutical and Personal Care Products. Water Research 43:55-62.

Moore, M. T., Greenway, S. L., Farris, J. L., and Guerra, B. (2008). Assessing Caffeine as an Emerging Environmental Concern Using Conventional Approaches. Archives of Environmental Contamination and Toxicology 54: 31-35. Mukhopadhyay, I., Nazir, A., Saxena, D. K., and Kar Chowdhuri, D. (2003). Heat Shock Response: hsp70 in Environmental Monitoring. Journal of Biochemical and Molecular Toxicology 17: 249-254.

Nakada, N., Kiri, K., Shinohara, H., Harada, A., Kuroda, K., Takisawa, S., and Takada, H. (2008). Evaluation of Pharmaceuticals and Personal Care Products as Water- 
Soluble Molecular Markers of Sewage. Environmental Science and Technology 42:6347-6353.

Nath, J. and Rebhun, L. I. (1976). Effects of Caffeine and Other Methylxanthines on the Development and Metabolism of Sea Urchin Eggs: Involvement of NADP and Glutathione. Journal of Cell Biology 68:440-450.

Parameswaran, P. S., Naik, C. G., and Govenkar, M. B. (2002). Secondary Metabolites from the Gorgonian Echinomuraceae splendens. Indian Journal of Chemistry $41: 1093-1096$.

Peeler, K. A., Opsahl, S. P., and Chanton, J. P. (2006). Tracking Anthropogenic Inputs Using Caffeine, Indicator Bacteria, and Nutrients in Rural Freshwater and Urban Marine Systems. Environmental Science and Technology $40: 7616-7266$.

Pereira, W. E., Moody, J. A., Hostettler, F. D., Rostad, C. E., Leiker, T. J. (1995). Concentrations and Mass Transport of Pesticides and Organic Contaminants in the Mississippi River and Some of its Tributaries;1987-89 and 1991-92; USGS Open-File Report; U.S. Government Printing Office: Washington, DC.

Pollack, K., Balazs, K., and Oginseitan, O. (2009). Proteomic Assessment of Caffeine Effects on Coral Symbionts. Environmental Science and Technology 43: 20852091.

Pyza, E., Mak, P., Kramarz, P., and Laskowski, R. (1997). Heat Shock Proteins (HSP70) as Biomarkers in Ecotoxicological Studies. Ecotoxicology and Environmental Safety 38:244-251.

Quinn, B. Gagne, F., and Blaise, C. (2008). An investigation into the acute and chronic toxicity of eleven pharmaceuticals (and their solvents) found in wastewater effluent on the cnidarian, Hydra attenuata. Science of the Total Environment 389:306-314.

Rana, N., Moond, M., Marthi, A., Bapatla, S. Sarvepalli, T., Chatti, K. and Challa, A. K. (2010). Caffeine-Induced Effects of Heart Rate in Zebrafish Embryos and Possible Mechanisms of Action: An Effective System for Experiments in Chemical Biology. Zebrafish 7:69-81.

Rounds, S. A., Doyle, M.C., Edwards, P. M., and Furlong, E. T. (2009). Reconnaissance of Pharmaceutical Chemicals in Urban Streams of the Tualatin River Basin, Oregon, 2002. USGS Open-File Report; U.S. Government Printing Office: Washington, DC.

Sanders, B. M. (1990). Stress Proteins: Potential as Multitiered Biomarkers. In L. Shugart and J. McCarthy 
(eds.) Environmental Biomarkers, pp. 165-191. Boca Raton, Florida: Lewis Publishers.

Sawyer, S. J. and Muscatime, L. (2001). Cellular Mechanisms Underlying Temperature-Induced Bleaching in the Tropical Sea Anemone Aiptasia pulchella. The Journal of Experimental Biology 204:3443-3456.

Siegener, R. and Chen, R. F. (2002). Caffeine in Boston Harbor Sea Water. Marine Pollution Bulletin 44:383-387. Singh, S. P., Azua, A., Chaudhary, A., Khan, S. Willett, K. L., and Gardineli, P. R. (2010). Occurrence and distribution of steroids, hormones and selected pharmaceuticals in South Florida coastal environments. Ecotoxicology 19:338-350.

Smith, G. R. and Burgett, A. A. (2005). Effects of Three Organic Wastewater Contaminants on American Toad, Bufo americanus. Ecotoxicology 14:477-482.

Staempfli, C., Becker-Van Slooten, K., and Tarradellas, J. (2002). Hsp70 Instability and Induction by a Pesticide in Folsomia candida. Biomarkers 7:68-79.

Standley, L. J., Rudel, R. A., Sawtz, C. H., Atfield, K. R., Christian, J., Erickson, M., and Brody, J.G. (2008). Wastewater-Contaminated Groundwater as a Source of Endogenous Hormones and Pharmaceuticals to Surface Water Ecosystems. Environmental Toxicology and Chemistry $27: 2457-2468$.

Stefano, G. B., Cadet, P., Zhu, W., Rialas, C. M., Mantione, K., Benz, D., Fuentes, R. Caseres, F., Fricchione, G. L., Fulop, Z., and Slingsby, B. (2002). The Blueprint for Stress Can Be Found in Invertebrates. Neuroendocrinology Letters 23:85-93.

Sun, T. and Tao, J. (2004). The Study of Pollutant Transport on the Action of Waves in the Near-Shore Area of Bohai Bay. Oceanologia et Limnologia 35:110-119.

Tang-Liu, D. D., Williams, R. L., and Riegelman, S. (1983). Disposition of Caffeine and Its Metabolites in Man. Journal of Pharmacology and Experimental Therapeutics $224: 180-185$.

Warrick, J. A., Mertes, L. A. K., Washburn, L., and Siegel, D. A. (2004). Dispersal Forcing of Southern California River Plumes, Based on Field and Remote Sensing Observations. Geo-Marine Letters 24:46-52.

Warrick, J. A., DiGiacomo, P. M., Weisberg, S. B., Nezlin, N. P., Mengel, M., Jones, B.H., Ohlmann, J.C., Washburn, L. Terrill, E. J., and Farnsworth, K. L. (2007). River Plume Patterns and Dynamics within the Southern California Bight. Continental Shelf Research 24:2427-2448. 
Washburn, L., McClure, K. A., Jones, B. H., and Bay, S. M. (2003). Spatial Scales and Evolution of Stormwater Plumes in Santa Monica Bay. Marine Environmental Research 56:103125 .

Weigel, S., Bester, K., and Huhnerfuss, H. (2001). New method for rapid solid-phase extraction of large-volume water samples and its application to non-target screening of North sea water for organic contaminants by gas chromatography-mass spectrometry. Journal of Chromatography 912:151-161.

Weigel, S., Kuhlmann, J., and Huhnerfuss, H. (2002). Drugs and Personal Care Products as Ubiquitous Pollutants: Occurrence and Distribution of Clofibric Acid, Caffeine, and DEET in the North Sea. The Science of the Total Environment 295: 131-141. Weigel, S., Berger, U., Jensen, E. Kallenborn, R., Thoresen, H., and Huhnerfuss, H. (2004). Determination of Selected Pharmaceuticals and Caffeine in sewage and Seawater from Tromso/Norway with Emphasis on Ibuprofen and Its Metabolites. Chemosphere 56:583-592.

Wheelock, C. E., Wolfe, M. F., Olsen, H. Tjeerdema, R. S., and Sowby, M. L. (1999). Hsp60-Induced Tolerance in the Rotifer Brachionus plicatilis Exposed to Multiple Environmental Contaminants. Archives of Environmental Contamination and Toxicology 36:281-287. 


\section{APPENDIX A: RECORD OF MODIFICATIONS TO INITIAL STUDY PROPOSAL}

This section is intended to provide a detailed record of all the modifications that were made to the study design and methodology of the initial study proposal. A copy of the study design and methodology of the initial study proposal is provided here for reference. Wherever a modification was made to the study design or methodology of the initial study proposal an endnote has been added providing an explanation of the reason for the modification and any other relevant details.

\section{STUDY DESIGN AND METHODOLOGY OF THE INITIAL STUDY PROPOSAL}

I. Quantifying environmental and organismal levels of caffeine

A. Field sampling sites ${ }^{1}$

Environmental and organismal levels of caffeine will be measured on the Oregon Coast based on two sampling plans (Table 1). Five rocky river-rocky-intertidal systems will be sampled on a monthly basis for one calendar year. Fifteen sites, including the five river-rocky-intertidal systems, five estuarine systems, and five rocky-intertidal systems that do not receive inputs from any significant rivers will be sampled in the summer (July 2008) and winter 
(December 2008). The five estuarine sites are expected to differ from the river-rocky-intertidal and rocky-intertidal sites because they are dominated by estuarine processes that may effect the concentration, retention, and processing of anthropogenic caffeine. Sampling during the summer (dry season) and the winter (wet season) will account for the effect of precipitation-induced run-off on the concentration of caffeine in coastal waters

The five paired river-rocky intertidal systems are the sites of ongoing studies by Dr. Elise Granek and were selected based on the following characteristics.

- Each basin has rocky intertidal habitat $<1 \mathrm{~km}$ from the river mouth.

- Estuarine processing in each system is likely to be reasonably slight due to the absence of major bays and attendant low water residence times, enhancing the potential for interactions between upland land-use and coastal ecosystem response.

- These watersheds fall along a gradient from fairly unaltered by human activity to more heavily impacted by human disturbance. This categorization of lightly to heavily disturbed watersheds will allow us to explicitly test whether differences in human population density are reflected in coastal community health and loads.

- Historic or current data on in stream water quality is available for each watershed.

The five estuarine sites and five rocky-intertidal areas that do not receive inputs from any significant 
rivers were selected based on their spatial distribution and the criteria briefly described above.

B. Sample collection

Water, sediment ${ }^{2}$, and organisms ${ }^{3}$ will be collected at each sampling site during each sampling event using the collection methods outlined below. At each river-rockyintertidal and rocky-intertidal site, tissue samples will be collected from Hedophyllum sessile kelp (slow growing), Ulva spp. macroalgae (fast growing), the filter-feeding mussel Mytilus californianus, and the predatory snail Nucella emarginata. At the estuarine sites, a common filter feeder (e.g. Crassostrea gigas) will be sampled to measure caffeine concentration in organismal tissue. All samples will be immediately placed on dry ice and transported to PSU, where they will be frozen at $-80^{\circ} \mathrm{C}$ until analyzed for caffeine.

- Water-3 "grab" samples will be collected below the surface in 1-L amber propylene bottles.

- Sediment- approximately 50 grams of surface sediments (1-3 cm) will be collected using a Dixie@ cup and stored in new Zip-lock@ bags covered with aluminum foil paper to impede photodegradation of caffeine. 
- Kelp/macroalgae- approximately three 15 grams samples will be scraped from rocks, lightly rinsed with deionized water, and stored in aluminum foil paper.

- Mytilus californianus- 5 individuals will be collected from three areas at each site, removed from the shell, and stored in aluminum foil paper.

- Nucella emarginata- approximately 10 individuals will be collected from three areas at each site, removed from the shell, and stored in aluminum foil paper. At the time of sample collection, a hand-held YSI with temperature and salinity probes will be used to record these parameters.

C. Caffeine analysis ${ }^{4}$

Levels of caffeine in water and sediment samples will be determined using established extraction, solid phase clean-up, and GC/MS procedures for the detection of environmental caffeine in freshwater and marine samples (Peeler et al. 2006). GC/MS analysis for caffeine will be run at WSU Vancouver in the laboratory of Dr. Steve Sylvester. Concentration of caffeine in the tissue of organisms will be measured employing the same procedures used for water and sediment (outlined below) after soxhlet extraction of freeze-dried tissue. 
i. Sample extraction

Prior to extraction, sediment and tissue samples

will be freeze-dried at the USGS Oregon Water Resources laboratory on the PSU campus. Dried samples will be ground using a mortar and pestle to facilitate extraction. Caffeine from sediment and tissue samples will be extracted with a soxhlet extraction system using organic solvents.

ii. Sample clean-up

Reversed phase solid-phase extraction (SPE) with LC $-18^{5}$ columns will be used to extract caffeine from liquid samples. Washing and elution will follow the procedure described by Peeler et al. (2006).

iii. GC/MS analysis ${ }^{6}$

A small aliquot ( $5 \mu L$ ) of the final sample will be injected into an Agilent GC/MS spectrometer. Samples will be chromatographed with the following GC/MS conditions: GC oven at $70{ }^{\circ} \mathrm{C}$ for one minute, followed by a $25{ }^{\circ} \mathrm{C}$ ramp to $180{ }^{\circ} \mathrm{C}$ (about 5 minutes), and finally a $5{ }^{\circ} \mathrm{C}$ ramp to $240^{\circ} \mathrm{C}$ (about 12 minutes). The final temperature will be held for approximately three minutes at the end of the run. The MS will be run in selected ion mode (SIM) to obtain the lowest detection 
limits possible. Peaks produced by the 194 and 197 ions will be used to quantify 12C-caffeine (natural) and 13C-caffeine (internal standard), respectively. iv. $\mathrm{QA} / \mathrm{QC}^{7}$

Liquid samples will be spiked ${ }^{13} \mathrm{C}$-labeled caffeine as an internal recovery standard. The ${ }^{13} \mathrm{C}$-caffeine internal recovery standard accounts for any losses during extraction (e.g., breakthrough during SPE) and GC/MS analysis assuming that ${ }^{12} \mathrm{C}$-caffeine and ${ }^{13} \mathrm{C}-$ caffeine are processed and analyzed with the same efficiency

II. Sub-lethal effects of caffeine (in lab caffeine exposure experiments)

A. Sample collection ${ }^{8}$

Live specimens of Mytilus californianus and Nucella emarginata will be collected from the 5 river-rockyintertidal areas. A minimum of 75 Mytilus californianus and 150 Nucella emarginata will need to be collected to run the in lab caffeine exposure experiments. Live specimens will be transported in coolers to PSU and maintained in recirculating salt-water aquaria in the laboratory of Dr. Brad Buckley.

B. In-lab caffeine exposure experiments ${ }^{9}$ 
In-lab caffeine exposure experiments will be conducted using identical caffeine exposure levels independently on the two invertebrate species of interest. For Mytilus californianus, $\mathrm{n}=5$ individuals will be held in 10-gallon tanks with filtered, temperature controlled, aerated seawater and exposed to one of five different doses of caffeine: $0,0.05,0.1,0.2$, and $0.5 \mu \mathrm{g}$ caffeine/L prepared from stock caffeine solutions. Each exposure level will be replicated in triplicate. After 3-week exposure period, individuals will be sacrificed and their tissue extracted. Tissue samples will be immediately frozen on liquid nitrogen to await biochemical analysis. Half of the tissue sample will be used to measure concentration of caffeine using the procedures outlined above for the extraction, clean-up, and GC/MS analysis of caffeine ${ }^{10}$. For Nucella emarginata, the same exact procedure will be followed with the exception that the number of individuals per dose will be $n=10$.

C. Immunohistochemistry for Quantitative Assessment of Stress Protein Production ${ }^{11}$

Immunohistochemistry or "western blotting" will be used to quantify the levels of Hsp70 and cytochrome P45012 in the tissues of mussels and snails exposed to caffeine. 
Tissues will be thawed and homogenized in a lysis buffer containing $10 \mathrm{mM}$ Hepes (pH 7.9), $10 \mathrm{mM} \mathrm{KCl,} 1.5 \mathrm{mM}$ MgCl2, $0.1 \mathrm{M}$ EDTA, $1 \mathrm{mM}$ DTT, $0.25 \% \mathrm{NP}-40,0.1 \mathrm{mM}$ PMSF and protease inhibitor cocktail (Sigma). Tissue extracts will be diluted $1: 1(\mathrm{v} / \mathrm{v})$ in $2 \mathrm{x}$ homogenization buffer, to a final concentration of $32 \mathrm{mM}$ Tris-HCl (pH 6.8) and $2 \%$ SDS. Homogenates will be heated at $100^{\circ} \mathrm{C}$ for $5 \mathrm{~min}$ and $\mathrm{C}$ centrifuged at $12,000 \mathrm{x} g$ for $10 \mathrm{~min}$. Pellets will be discarded, and total protein content of the supernatants will be determined by Bradford assay (Pierce, Rockford, IL, USA). Equal amounts of protein from each sample will be separated according to molecular mass, via SDSpolyacrylamide gel electrophoresis (SDSPAGE), on $7.5 \%$ polyacrylamide gels. Following $1.5 \mathrm{~h}$ electrophoresis at 150 V, proteins will be transferred to nitrocellulose blots, via semi-dry electrotransfer for $1.5 \mathrm{~h}$ at $150 \mathrm{~V}$.

Blots will be blocked for 1 h in 5\% non-fat dry milk (NFDM) in 1 X PBS under constant shaking. Blots will be washed 3 times for $5 \mathrm{~min}$ in $1 \mathrm{x}$ PBS containing $0.01 \%$ Tween20. Following washes, blots will be incubated in primary antibody (1:1,000 dilution in $1 \mathrm{X}$ PBS containing 5\% NFDM) for $1.5 \mathrm{~h}$. Blots will be incubated in a primary antibody against either Hsp70 or cytochrome P450 (Santa Cruz 
Biotechnology) for $1.5 \mathrm{~h}$ at room temperature. Following incubation in primary antibody, blots will be washed $3 \times 10$ min in 1 X PBS with $0.1 \%$ Tween-20, then incubated in a secondary antibody (horseradish peroxidase conjugated Protein A, 170-6522, BioRad) at a dilution of $1: 5000$ in $1 \mathrm{X}$ PBS containing 5\% NFDM. Blots will be washed a final time and exposed to enhanced chemiluminescent reagent (ECL, Amersham), for 5 min. Blots will be wrapped in plastic wrap and exposed to X-ray film (XOMAT-AR film, Kodak). Densitometry will be conducted on blots using ImageMaster software (Amersham); all experimental values will be standardized to the control values.

\footnotetext{
${ }^{1}$ Samples were collected from the locations listed in the initial study proposal. The results from those samples were invalidated due to analytical issues, high levels of blank contamination, and inadequate $\mathrm{QA} / \mathrm{QC}$. The sample results reported in this study were analyzed in a different laboratory, after modifying the collection and filtering procedure. The collection and filtering procedures used is reported in the methods section of Chapter 2. Briefly, more rigorous procedures were used to avoid potential sample contamination; the filtering procedure was modified to
} 
minimize sample handling; and stricter $\mathrm{QA} / \mathrm{QC}$ procedures were established.

${ }^{2}$ Sediment samples were not collected due to the lack of an established procedure by the analyzing laboratory and to time limitations for establishing a procedure and testing its performance.

${ }^{3}$ Organism samples were not collected due to the lack of an established procedure by the analyzing laboratory and to time limitations for establishing a procedure and testing its performance.

${ }^{4}$ Samples were analyzed for caffeine at Portland State University in the laboratory of Dr. James Pankow. ${ }^{5}$ Sample water was passed directly from the sample bottle to a GF/C glass microfibre filter (Whatman $1.2 \mu \mathrm{m}$ ) mounted on to a Swinnex filter holder and then through and ENVI-Carb SPE tube (Supelclean) using uninterrupted flow set to approximately $5 \mathrm{ml} / \mathrm{min}$.

${ }^{6}$ Various modifications were made to the GC-MS procedure. The GC-MS conditions are detailed in the methods section of Chapter 2 .

${ }^{7} \mathrm{QA} / \mathrm{QC}$ was found to be inadequate. Modifications included running a minimum of 1 field blank per every five samples that were analyzed. For each GC-MS run a fresh batch of 
calibration standards was made up and analyzed at the beginning of the run. Check standards prepared by an independent party were also analyzed with each run. ${ }^{8}$ Caffeine exposure experiments with Nucella emarginata were not conducted due to time limitations.

${ }^{9}$ The caffeine exposure experiment using Mytilus californianus was performed according to the design outlined in the initial procedure. Initially, the temperature in the experimental tanks was going to be controlled by maintaining a controlled temperature in the room and having temperature data loggers in each tank. However, due to construction in the building that was affecting power to one of the air conditioning units in the tank room, it became impossible to maintain a satisfactory temperature in the room. Several mussels died and the tanks became fouled. As a result, the experiment was aborted and the sampling design was modified. Sealine in-line chillers were used to maintain the temperature in the tanks. Since it was logistically impossible to set up the 15 chillers that would have been required to complete the experiment as planned, the experiment was modified, as outlined in the methods section of Chapter 3. Briefly, all mussels exposed 
to one of five doses of caffeine were placed in the same experimental tank.

${ }^{10}$ Tissue analysis for caffeine was not performed due to the lack of an established procedure by the analyzing laboratory and to time limitations.

${ }^{11}$ Some modifications were made to the western blotting procedure based on the methodology used by the host lab. The details of the method used are listed in the methods section of Chapter 3 .

${ }^{12}$ Western analysis for Cytochrome P450 was not completed. The commercial antibody CYP1A1, rabbit polyclonal igG (Santa Cruz Biotechnology) failed to react with mussel tissue and consistently produced blank blot films. Due to time limitations, an alternative antibody was not tested. 